\title{
Mitigation of Ecuadorian Earthquake Impact
}

\author{
Tai-Jin Kim \\ Department of Chemical Engineering, The University of Suwon, Hwasung-City, Republic of Korea \\ Email: tjkim@suwon.ac.kr
}

How to cite this paper: Kim, T.-J. (2018) Mitigation of Ecuadorian Earthquake Impact. Open Journal of Earthquake Research, 7, 195-219.

https://doi.org/10.4236/ojer.2018.73012

Received: July 17, 2018

Accepted: August 17, 2018

Published: August 20, 2018

Copyright $\odot 2018$ by author and Scientific Research Publishing Inc. This work is licensed under the Creative Commons Attribution International License (CC BY 4.0).

http://creativecommons.org/licenses/by/4.0/

\begin{abstract}
The mechanism of "Bing-Bang-Channeling-Cut" was proposed to reduce the volcanic energy ("Bing") from the Galapagos Hot Spot (GHS) for the mitigation of Ecuadorian earthquake impact ("Bang"). The lag time between the volcanic eruptions in the GHS and Ecuadorian earthquake was probably caused by the undersea seamounts of the Carnegie Ridge (CAR) ("Channeling"). Experimental results from the water reservoir showed that the lag time decreased when increasing the number of drilled holes ("Cut") in the bottom of reservoir. The present study showed that there was an additional vector initiating the Ecuadorian earthquake from the volcanic eruption in the GHS through the CAR. It was concluded that the harmful effects of Ecuadorian earthquakes could be mitigated by releasing the volcanic energy through the enlarged exit diameters in Holes of Site 1239 (A, B, C) with the presently productive upwelling chlorophyll system at the northeastern CAR.
\end{abstract}

\section{Keywords}

Ecuador, Earthquake, Volcano, Mitigation, Hole

\section{Introduction}

Throughout the year of 2016 there were strong earthquakes around the world. They include earthquakes in India (4 January, M 6.7), Taiwan (China) (6 February, M 6.4), Japan (15 April, M 7.3), Ecuador (16 April, M 7.8), Myanmar (24 August, M 6.8), Italy (24 August, M 6.2), New Zealand (13 November, M 7.8), and Indonesia (6 December, M 6.5), among which the strongest and the deadliest one was the Ecuadorian earthquake with a death toll of 673. Ecuador's recorded seismic history dates back to 1541, and records show a cumulative death toll of more than 80,000 [1]. The Galapagos Islands are reported to be a "hot spot", which is the region of high thermic flux due to the presence of a magmatic plume ascending from the earth's mantle (700 - $3000 \mathrm{~km})$ [2]. Galapagos Islands are basaltic rocks produced by volcanic activities caused by magma upwelling $\left(700^{\circ} \mathrm{C} \sim 1300^{\circ} \mathrm{C}\right)$ in the Galapagos Hot Spot (GHS). The hot energy side of the 
internal thermic magma after volcanic eruption in the GHS is transferred to the cold energy side of the undersea seamount of the Carnegie Ridge (CAR), which is a volcanic plateau formed during the eastward movement of the new Nazca Plate over the GHS [3].

The seafloor of the Galapagos Island is characterized by a platform on which all its islands are settled. Geomorphologic is formed by the Carnegie Ridge (CAR), Cocos Ridge (COC), and Colon Ridge (CLR), which are considered a natural extension of the Ecuador Insular Platform (EIP). These three ridges can be classified as submarine ridges, although they have oceanic crust formation, since their crust is different from the adjacent seabed [4]. There is a Northern Volcanic Zone of South America and Ecuadorian Trench in Ecuador, where the Nazca Plate enters the South American Plate. Therefore, there could be earthquakes, as observed in the 1964 Great Alaska Earthquake which followed the Aleutian Trench and Aleutian Volcanic Arc [5]. Due to these factors, the Arc enters the North of Ecuador rapidly along strike affecting Ecuador. The results can be classed as follows: 1) result from movement on the subduction interface along the plate boundary, 2) result from deformation within the South American and Nazca Plate, and 3) associated with active volcanoes.

The purpose of the present study was to analyze 42 inland earthquakes (24 in Ecuador, 16 in Colombia, 2 in Peru) out of 55 events that occurred from 1977 to 2016. Mitigation of the Ecuadorian earthquake impact ("Bang") was investigated by releasing volcanic energy from the GHS ("Bing") through drilled Holes ("Cut") at the undersea seamount of the CAR ("Channeling").

\section{Initiative Experiment}

An initiative experiment was designed to examine the distribution of potential energy of a water reservoir with the increase of the number of drilled holes. The water reservoir (diameter $=44 \mathrm{~cm}$, height $=43 \mathrm{~cm}$ ) was prepared to release its water stepwise through 12 drilled holes $(\mathrm{ID}=0.4 \mathrm{~cm}$ ) at the bottom side, as shown in Figure 1.

Lag time, as a function of hole number for the release of reservoir water from the top ( $40 \mathrm{~cm}$ high) to the bottom, is analogous to the lag time of occurrences between the volcanic eruptions in the GHS and the Ecuadorian earthquake, as shown in Figure 2(a). The lag time decreased with the increase of drilled holes exponentially (Figure 2(b)). The regression equation between the lag time $(t)$ and the number of drilled hole $(n)$ is given by, $\ln t=-0.195 n+7.74$ with $R^{2}=0.879$. For the sudden release of the reservoir water $(\ln 1=0)$ in the present system, the number of holes should be about $40(n=40)$.

\section{Results and Discussion}

\subsection{Carnegie Ridge with Similarity between Ecuadorian and Mexican Earthquakes}

The buoyancy of the subducted CAR would explain the flatness of the slab beneath Ecuador. The CAR is an $\sim 200 \mathrm{~km}$-wide oceanic plateau abutting the 


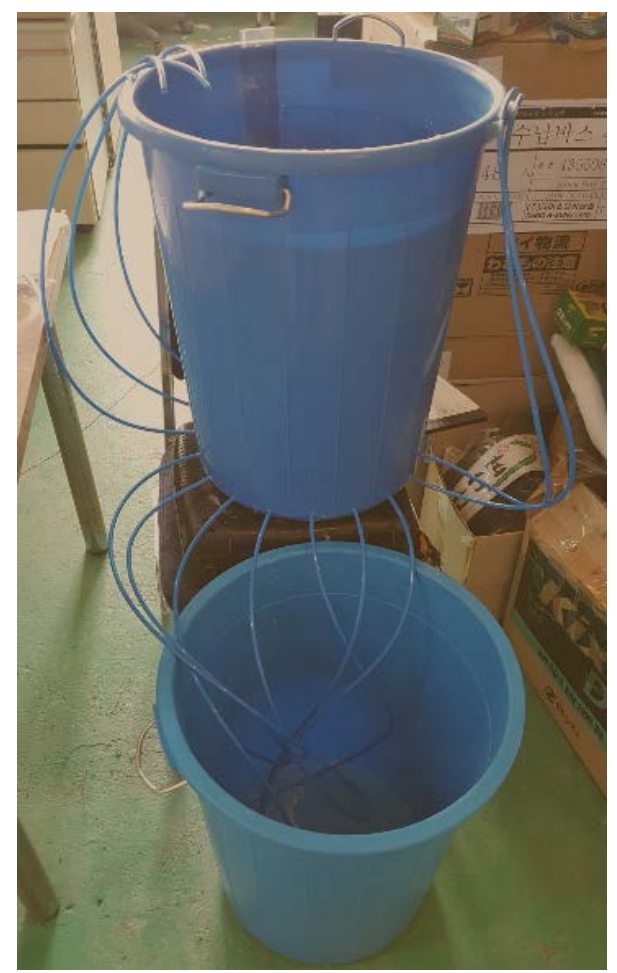

Figure 1. Water reservoir $(\mathrm{D}=44 \mathrm{~cm}, \mathrm{H}=43 \mathrm{~cm})$ and 12 releasing holes $(\mathrm{ID}=0.4 \mathrm{~cm}$ ) at the bottom for the response time experiment of potential energy change with reservoir height.

Ecuadorian Trench. Off the Ecuadorian margin $\left(3^{\circ} \mathrm{S}-1^{\circ} \mathrm{N}\right)$ close to the Ecuadorian Trench, the CAR presents a relief up to $1000 \mathrm{~m}$ in depth and a crustal thickness ranging from $14 \mathrm{~km}$ to $19 \mathrm{~km}$. Many geologic features of Ecuador are commonly ascribed to the CAR subduction. The depth of the Trench off Ecuador (at the CAR subduction zone) is less than $2800 \mathrm{~m}$, whereas in offshore Peru and Colombia, it is up to $3700 \mathrm{~m}$ depth, indicating that the CAR is currently subducting at the Trench. The thick CAR crust extends at least $60 \mathrm{~km}$ beneath the upper plate during earthquakes. Coastal uplift opposite the CAR is indicated by marine terraces exposed at $200-300 \mathrm{~m}$ as the uplift of the Ecuadorian coast to the subduction of the CAR. The Coastal Cordillera is an $\sim \mathrm{N}$-S-trending chain located $\sim 120 \mathrm{~km}$ east of the Trench. To the east, it limits the marine terraces observed along the Ecuadorian coast. The highest points of the Coastal Cordillera of Ecuador are $\sim 600-700 \mathrm{~m}$ above sea level. The uplift of the Coastal Cordillera probably altered the drainage patterns and associated sediment transfer. The main mechanism for increasing the geothermal gradient may have been the flattening of the slab produced by the subduction of the CAR. Under such conditions, the subducted slab would have remained under pressure-temperature $(P-T)$ conditions that allowed partial melting to occur for a long period of time. The slab is not flat beneath Ecuador, but, instead it regularly dips to the east with an angle of $25^{\circ}-35^{\circ}$. Estimates derived from [6] showed that geological expression 


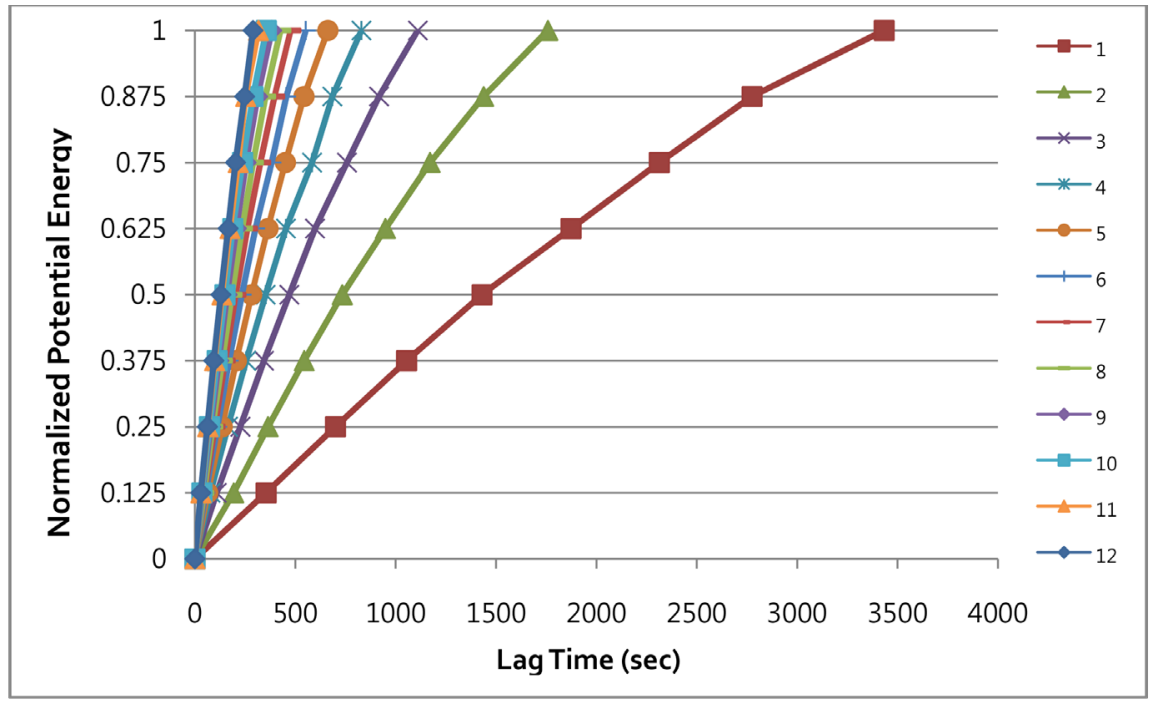

(a)

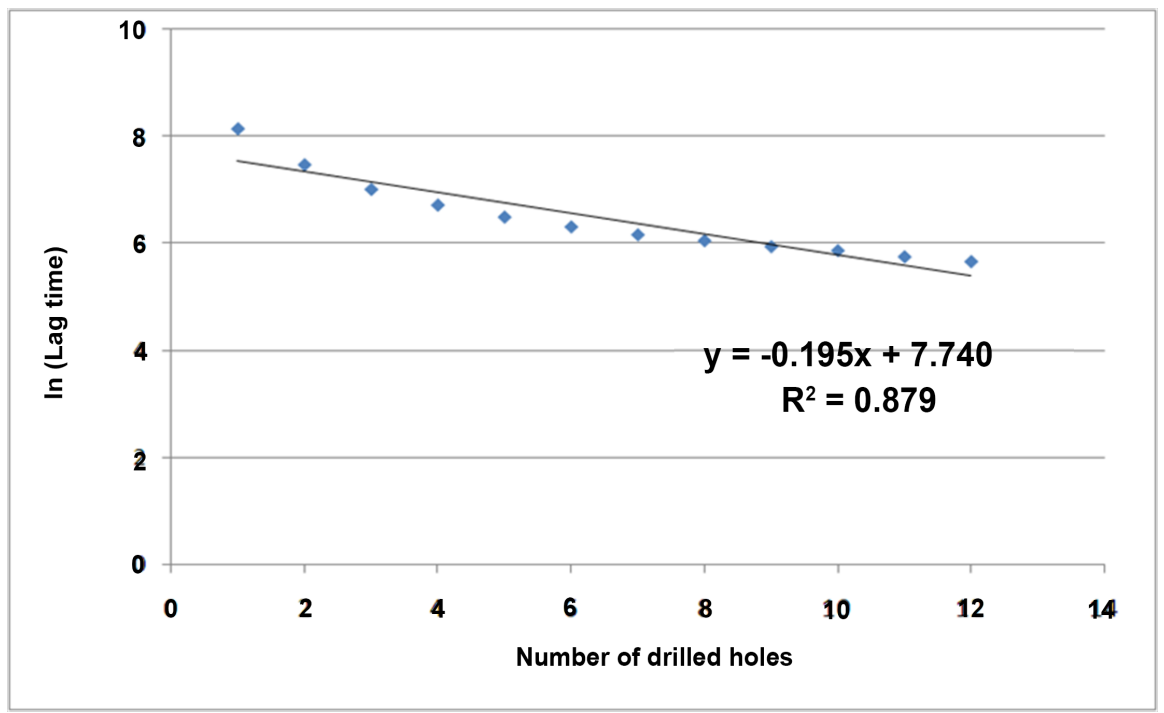

(b)

Figure 2. (a) The lag time distribution of the normalized reservoir potential energy with respect to the initial reservoir water height as a function of 12 drilled holes at the bottom of the water reservoir; (b) The regression equation between the lag time $(t)$ and the number of drilled holes $(n)$ is given by, $\ln t=-0.195 n+7.74$ with $R^{2}=0.879$. For the sudden release of the reservoir water $(\ln 1=0)$ in the present system, the number of holes should be about $40(n=40)$.

of subduction of the CAR only requires a $300 \mathrm{~km}$ penetration of the CAR beneath Ecuador.

The direction of energy transfer from the CAR to Ecuador should be perpendicular to the surface between the CAR and Ecuador Continental Shelf (ECS) according to the principle of Pascal. The coastal margin of Ecuador comprises Pliocene sediments of marine terraces (Tablazos) [7] such as Esmeraldas, Manta, and Santa Elena [8]. Major Ecuadorian earthquakes mainly occurred in the northwestern Ecuador over Tablazos of marine terraces and Coastal cordillera 
[9], which produced strong and deadly earthquakes in 1906 (Esmeraldas) (Mw 8.8), 1942 (Guayaquil) (Mw 7.9), 1958 (Esmeraldas) (Mw 7.6), and 1979 (December 12, Tumaco) (Mw 8.2) [9], and 2016 (April 16, Muisne) (Mw 7.8). It is interesting to note that there were corresponding volcanic eruptions in the GHS prior to Ecuadorian earthquakes; Santiago (1906), Ambrym (1942), Sierra Negra (1957), Ambrym (1958), Fernandina (1958), and Sierra Negra (1979) (November, 2 weeks), and Wolf (May 25, 2015) volcanoes. Similar patterns have been observed in Mexican earthquakes as follows.

Local constructional volcanism was at a distances of $2 \mathrm{~km}$ for 12 high- and 9 low- temperature hydrothermal vents along the East Pacific Rise (EPR) axis between $9^{\circ} 49^{\prime}-51^{\prime} \mathrm{N}$ (the Clipperton and Siqueiros transforms). There were actively venting black smokers with chimney structures of Tube Worm Pillar (Figure 3) in 1991, 1992, 1994, 1996, 1997, 1998, and 2002, during which no earthquakes occurred in Mexico. On the other hand, earthquakes were observed in 1985, 1995, 1999, 2003, and 2009 in Mexico [10]. It was thus postulated that high-temperature $\left(\geq 350^{\circ} \mathrm{C}\right)$ hydrothermal black smoker vents released the thermal energy of the EPR continuously, so that no earthquakes have occurred during such venting periods in Mexico, whose western coast is in junction with the EPR.

The numbers of volcanoes and earthquakes in Table 1 were added together to get the overall numbers in large order in Chile (270), Mexico (106), Peru (85), Ecuador (68), Guatemala (54), Colombia (41), El Salvador (38), Nicaragua (8). The order is in good agreement with Figure 4 of the solar radiation map except Ecuador, which has a low solar radiation energy. On the other hand, Ecuador has many volcanoes (43) and earthquakes (24) in Table 1. It can be thus postulated that the required energy for the plate movement to cause Ecuadorian volcanic eruptions and earthquakes is provided by the volcanic energy in the GHS via submarine CAR of Nazca Plate which is subducted beneath Ecuador of South American Plate in convergent plate boundary associated with Ecuadorian volcanoes and earthquakes.

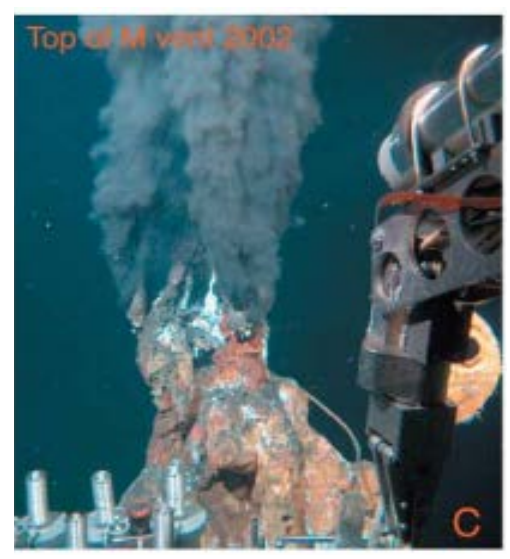

Figure 3. Chimney structure of high-temperature hydrothermal vent with black smokers along the East Pacific Rise (EPR) in 2002 [10]. 


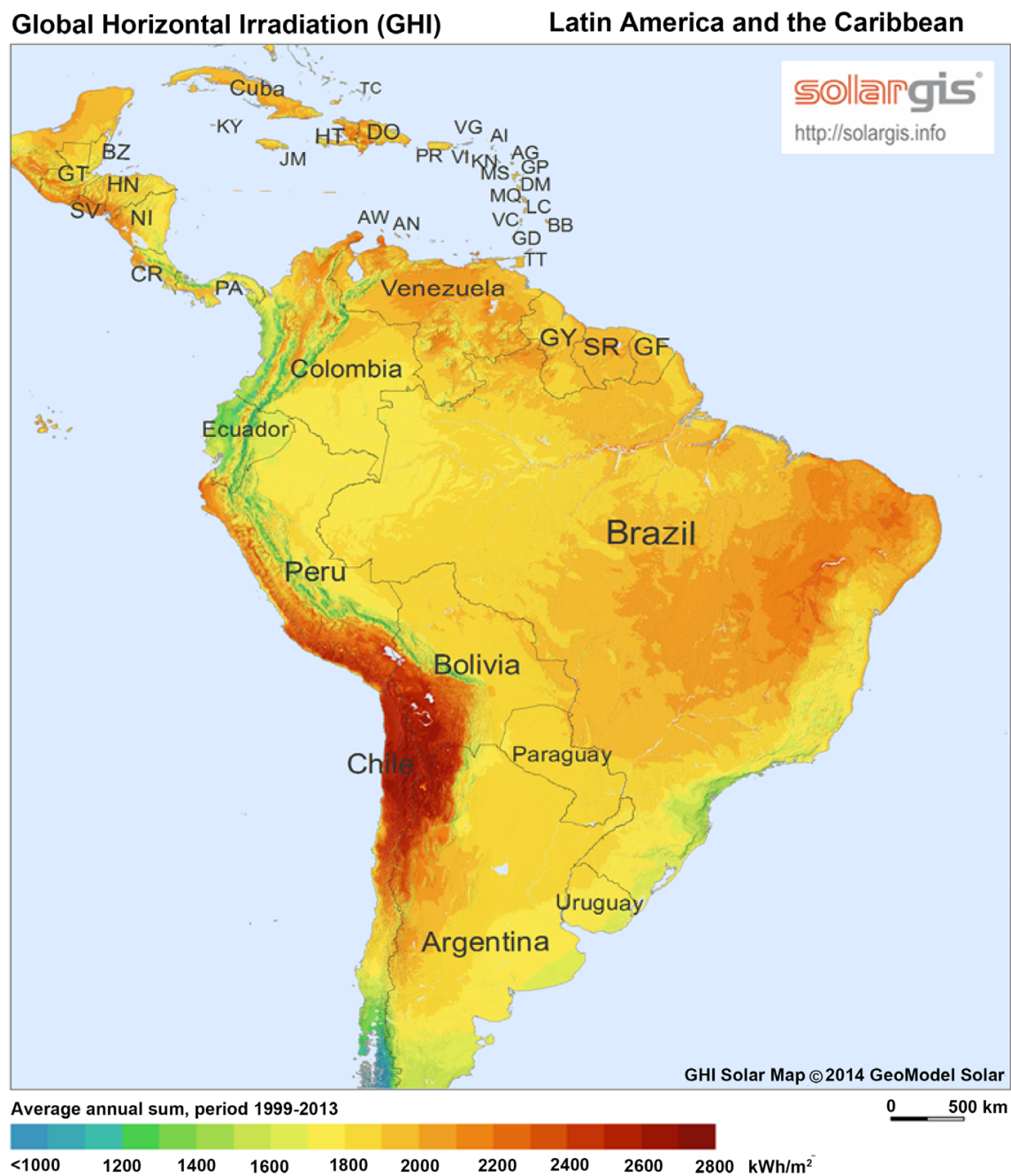

Figure 4. Global horizontal irradiation of South America and Central America [11].

Table 1. Volcano, earthquake and ridge in east Pacific and Central American countries.

\begin{tabular}{cccc}
\hline Country & $\begin{array}{c}\text { Volcano } \\
\text { Number }\end{array}$ & $\begin{array}{c}\text { Earthquake } \\
\text { Number }\end{array}$ & Ridge \\
Costa Rica & 13 & 11 & $\begin{array}{c}\text { Cocos (Costa Rica Province, Cocos Island } \\
\text { Province, Southwest Province) }\end{array}$ \\
Panama & 3 & 4 & Coiba \\
Colombia & 16 & 25 & Carnegie/Malpelo/Columbia-Ecuador \\
Nicaragua & 19 & 9 & Trench \\
Ecuador & 43 & 24 & Nicaraguan fore-are \\
Guatemala & 29 & 25 & Middle American Trench \\
Honduras & 4 & 3 & Middle American Trench \\
Peru & 29 & 56 & Nazca \\
El Salvador & 22 & 16 & Middle American Trench \\
Chile & 137 & 133 & Tehuantepec/East Pacific Rise \\
Mexico & 42 & 64 & Chile Rise
\end{tabular}


It is thus necessary to release the overall energy retained at the CAR prior to being delivered in the form of disastrous Ecuadorian earthquake.

\subsection{Energy Balance over the CAR}

As conceptually drawn in Figure 5, the energy flow from volcanic eruptions in the GHS to Ecuadorian earthquakes was divided into 3 steps.

1) "Bing" step; volcanic eruption in the GHS,

2) "Channeling" step; Ecuador Insular Shelf (EIS), CAR, Ecuadorian Trench, Ecuador Continental Shelf (ECS) [4],

3) "Bang" step; Ecuadorian earthquake (Tablazos, Coastal cordillera, Cordillera occidental, Cordillera real, Sub-Andean zone).

Thermal energy $(Q)$ produced by volcanic eruption in the GHS is transferred to the CAR due to CAR formation of volcanic plateau over the GHS [3]. This thermal energy $(Q)$ is converted to work $(W)$ by exerting force $(F)$ with displacement change $(\Delta x)$. Since pressure $(P)$ is the force $(F)$ per unit area $(A)$, energy $(Q)$ can be expressed as,

$$
Q=P \cdot A \cdot \Delta x
$$

Unsteady state energy balance over the CAR is given by,

$$
\frac{\mathrm{d} Q}{\mathrm{~d} t}=\dot{Q}_{\text {in }}-\dot{Q}_{\text {out }}+\dot{Q}_{\text {gen }}-\dot{Q}_{\text {con }}
$$

where $\dot{Q}_{\text {in }}$ is the input rate of energy from volcanic eruptions in the GHS,

$\dot{Q}_{\text {out }}$, the output rate of energy to Ecuador, Panama Basin, and Peru Basin,

$\dot{Q}_{g e n}$, the generation rate of energy by volcanoes in the CAR,

$\dot{Q}_{\text {con }}$, the consumption rate of energy by earthquakes in the CAR.

At steady state, $\frac{\mathrm{d} Q}{\mathrm{~d} t}=0$ in Equation (2).

$\dot{Q}_{i n}$ is assumed to be, the volcanic thermal energy in the GHS $\left(\dot{Q}_{G}\right)$, i.e. $\dot{Q}_{i n}=\dot{Q}_{G}$

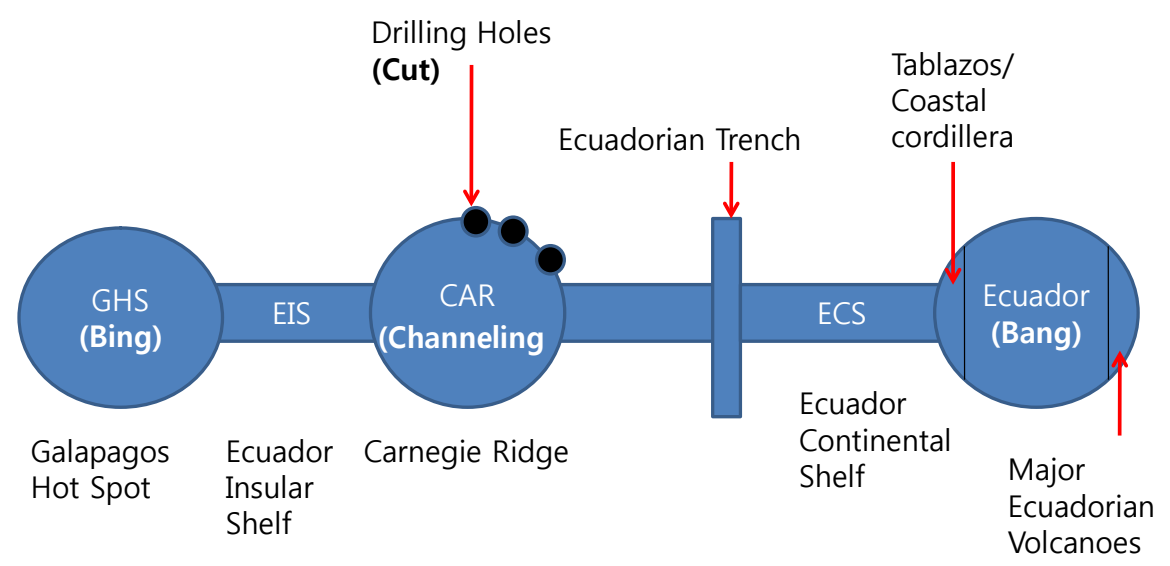

Figure 5. Schematic diagram of energy flow between the GHS ("Bing") and Ecuador ("Bang") through the Ecuador Insular Shelf (EIS), CAR ("Channeling”) with northeastern drilled Holes of Site 1239, A, B, C (“Cut”), Ecuadorian Trench, Ecuador Continental Shelf (ECS), Tablazos, Coastal cordillera, and Ecuador with Major Ecuadorian Volcanoes. 
$\dot{Q}_{\text {out }}$ is defined as the sum of, the energy flow rate causing the earthquake in Ecuador $\left(\dot{Q}_{E}\right)$, and, the energy flow rate through the drilled Holes in the CAR $\left(\dot{Q}_{H}\right)$, i.e. $\dot{Q}_{\text {out }}=\dot{Q}_{E}+\dot{Q}_{H}$

Since the CAR was seismically estimated to be $\sim 20$ and $\sim 11.5 \mathrm{Myr}$ old seafloor over the Nazca Plate in the Galapagos Volcanic Plateau (GVP) [12], $\dot{Q}_{g e n}$ and $\dot{Q}_{\text {con }}$ in Equation (2) are negligible.

Therefore, Equation (2) is simplified as,

$$
\dot{Q}_{E}=\dot{Q}_{G}-\dot{Q}_{H}
$$

It is evident that the energy flow rate causing the Ecuadorian earthquake $\left(\dot{Q}_{E}\right)$ becomes small with the increase of the energy flow rate through the drilled Holes in the CAR $\left(\dot{Q}_{H}\right)$ for the given volcanic eruptions in the GHS $\left(\dot{Q}_{G}\right)$

Sub-aerial volcanoes and submarine seamounts absorb the sunlight and convert it into thermal energy with heat transfer mediums like magma, lava, air and seawater. Incoming solar radiation is $174 \mathrm{PW}$ while $89 \mathrm{PW}$ is absorbed by land and oceans [13]. As $71 \%$ of the Earth's surface is the Ocean, the oceanic solar radiation is $63 \mathrm{PW}(=89 \times 0.71)$. Since more than 100,000 submarine volcanic seamounts $(>1 \mathrm{~km}$ in height) are present in the Ocean [14], there is an oceanic solar energy of about $630 \mathrm{MW}\left(=63 \times 10^{12} \mathrm{~W} / 10^{5}\right.$ seamounts $)$, absorbed to the CAR. Since $1 \mathrm{MW}$ is equivalent to $10^{6} \mathrm{~J} \cdot \mathrm{s}^{-1}$ to have $\dot{Q}_{S}=5.4 \times 10^{13} \mathrm{~J} \cdot \mathrm{d}^{-1} \quad\{=(6.3$ $\left.\left.\times 10^{8} \mathrm{~J} \cdot \mathrm{s}^{-1}\right) \times\left(3600 \mathrm{~s} \cdot \mathrm{h}^{-1}\right) \times\left(24 \mathrm{~h} \cdot \mathrm{d}^{-1}\right)\right\}$. This is the case if we apply the mean lag time of 287 days ( \pm 219 days) between Galapagos volcanoes and 55 inland earthquakes (Table 1) as $Q_{S}=1.6 \times 10^{16} \mathrm{~J} \quad\left\{=\left(5.4 \times 10^{13} \mathrm{~J} \cdot \mathrm{d}^{-1}\right) \times(286 \mathrm{~d})\right\}$ or earthquake moment magnitude scale of $\mathrm{Mw}=4.75$ [15]. The volcanic energy rate from the GHS $\left(\dot{Q}_{G}\right)$ is transferred to the CAR with similar geological characteristics for resonant thermal energy rate with amplification. Solar radiation energy rate over the CAR is about $\mathrm{Mw}=4.75$, which is additionally propagated to Ecuador with activated energy by oscillatory behavior at Tablazos. The ultimate thermal energy rate of Ecuadorian earthquake $\left(\dot{Q}_{E}\right)$ can be cumulative with, 1) the initial volcanic energy rate $\left(\dot{Q}_{G}\right)$ from the GHS, 2) the resonant energy rate from the CAR with similar materials of the GHS $\left.\left(\dot{Q}_{R}\right), 3\right)$ solar radiation energy rate over the CAR $\left(\dot{Q}_{S}\right)$, and 4$)$ activated energy rate by oscillatory behavior in the northwestern Ecuadorian Tablazos $\left(\dot{Q}_{T}\right)$. Since all the energy rates are not controllable unless releasing the main $\dot{Q}_{G}$ in advance, it is important to use the drilled Holes of Site 1239 A, B, C in the northeastern CAR to release volcanic energies for mitigation of Ecuadorian earthquake impacts. The Hole diameters of the Site 1239 in the CAR were $0.3 \sim 0.4 \mathrm{~m}$ (11.5 15 in) with core depth from $114 \sim 515 \mathrm{~m}$ for Holes A, B, and C [16]. Most of the cores were odoriferous $\left(\mathrm{H}_{2} \mathrm{~S}\right)$, which implies that there are actively venting black smokers with chimney structures of Tube Worm Pillar (Figure 3) in CAR. It is therefore possible that Ecuadorian earthquakes can be mitigated during venting periods, as observed in Mexican earthquakes [10]. Local constructional volcanism was at a distance of < $2 \mathrm{~km}$ in EPR [10] while CAR-Ecuador margin collision length is $160 \mathrm{~km}$ [8]. Considering the CAR margin, it is suggested that $80(=160 / 2)$ drilled holes be 
made at the depth contour of $2500 \mathrm{~m}$ (Figure 6). On the other hand, systematic dredging of the East Pacific Rise (EPR) had an average spacing of $8 \mathrm{~km}$ segmentation [17] to have $20(=160 / 8)$ drilled holes. Since there were no earthquakes in Mexico with 21 hydrothermal vents along the EPR [10], about 20 drilled holes are approximately required in the northeastern CAR for the mitigation of Ecuadorian earthquake impacts. Instead of drilling 20 additional holes, however, it may be easier to enlarge diameters of the present three Holes (A, B, C) of Site 1239 from $0.3 \sim 0.4 \mathrm{~m}$ to $0.6 \sim 0.8 \mathrm{~m}$. Since the flow rate is proportional to the square of tube diameter, 3 Holes with twice (2) increase of diameters $\left(2^{2}=4\right)$ make 12 equivalent Holes ( 3 Holes $\times 4$ flow rates $=12$ Holes).

\subsection{Drilled Holes}

Locations of Sites 1238-1242 near CAR are shown in Figure 6.

There can be prospective locations for drilling vents as below.

1) Hydrothermal $\left(\geq 350^{\circ} \mathrm{C}\right)$ vent $[10]$,

2) Black smoker vents by insoluble black $\mathrm{FeS}$ and $\mathrm{FeS}_{2}$ during volcanic eruption,

3) Tube Worm Pillar growing area due to its preference of $\mathrm{H}_{2} \mathrm{~S}$ [19],

4) Coral bleaching area caused by stress changes in temperature, light, or nutrients to expel the symbiotic algal for complete white [20].

There can be momentum $(\dot{m})$ and heat flow $(\dot{Q})$ rates as follows,

$$
\begin{gathered}
\dot{m}=\rho u S \\
\dot{m}=\rho u\left(\frac{\pi}{4} D^{2}\right) \\
\dot{Q}=\dot{m} C_{P} \Delta T
\end{gathered}
$$

Equations (5) and (6) reduce to,

$$
\dot{Q}=\rho u\left(\frac{\pi}{4} D^{2}\right) C_{P} \Delta T=\left(\frac{\pi}{4} \rho C_{P}\right) u D^{2} \Delta T
$$

where

$\dot{Q}=$ heat flow rate through drilling vent,

$\rho=$ density of undersea water,

$C_{P}=$ heat capacity of undersea water,

$u=$ linear flow velocity passing through drilling vent,

$D=$ diameter of drilling vent,

$\Delta T=$ temperature difference between vent exit $\left(T_{2}\right)$ and vent surrounding $\left(T_{1}\right)$.

In order to release high hydrothermal flux $(\dot{Q})$ through drilling vents, it is necessary to enlarge the diameter $(D)$ in Equation (7).

There were drilling Sites of $1239\left(0^{\circ} 40.32^{\prime} \mathrm{S}, 82^{\circ} 4.86^{\prime} \mathrm{W}\right)$ and $1238\left(1^{\circ} 52.310^{\prime} \mathrm{S}\right.$, $\left.82^{\circ} 46.934^{\prime} \mathrm{W}\right)$ at $1414 \mathrm{~m}$ and $2209 \mathrm{~m}$ depth of CAR, respectively. In Site 1239, there were 3 Holes; 1239A with cored lengh of $515.4 \mathrm{~m}, 1239 \mathrm{~B}-396.7 \mathrm{~m}$, and 1239C - $114 \mathrm{~m}$ [16]. As shown in Figure 6(b), Site 1239 revealed the highly 


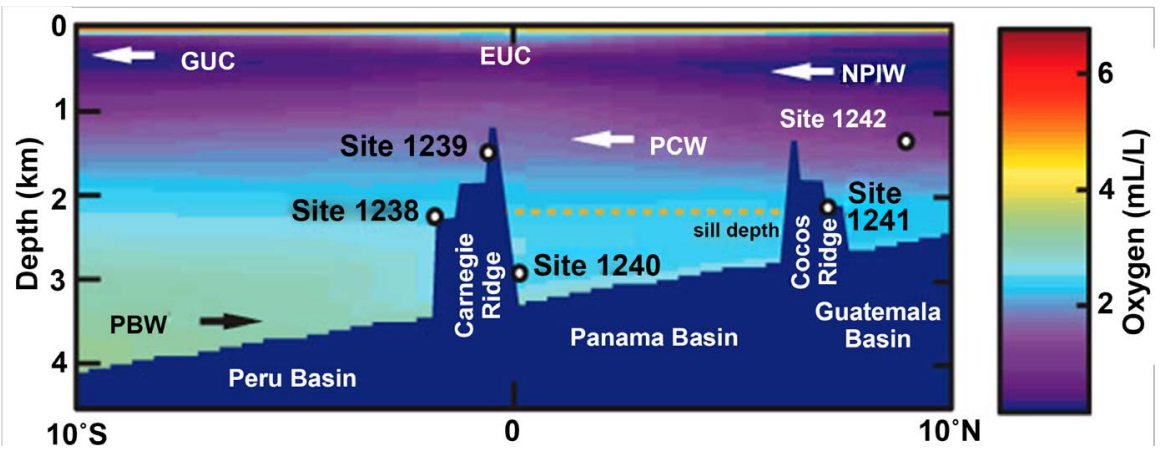

(a)

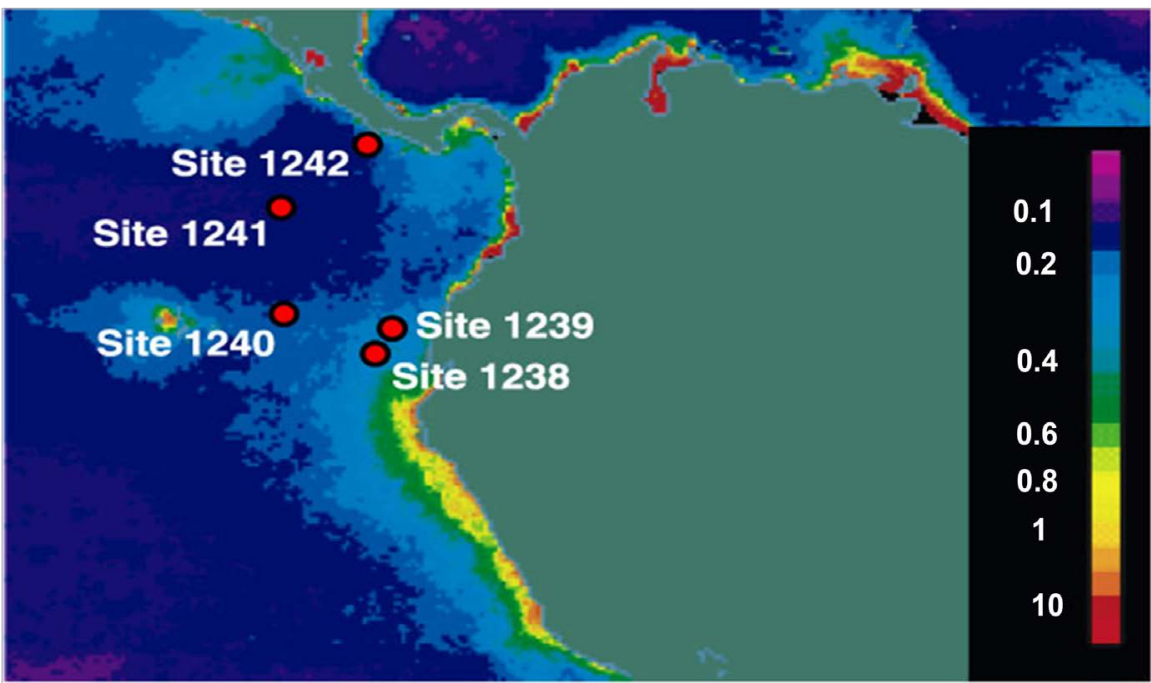

(b)

Figure 6. (a) Meridional cross section of water masses, characterized by dissolved oxygen concentrations in the southeast Pacific [18]. GUC = Gunther Undercurrent, EUC = Equatorial Undercurrent, NPIW $=$ North Pacific Intermediate Water, PCW $=$ Pacific Central Water, PBW = Peru Basin Water; (b) Chlorophyll distributions in surface waters of the equatorial Pacific, based on satellite color data, reveal that Site 1239 is now within the highly productive upwelling system off Ecuador [16].

productive upwelling system off Ecuador for chlorophyll distribution. Therefore, Holes of Site 1239 (A, B, C) might produce the geothermal energy released from the volcanic eruption in the GHS through the undersea seamounts of the CAR. Since there were enriched $\mathrm{H}_{2} \mathrm{~S}$ around such Holes, the vents diameter can be enlarged to release more internal energy retained by CAR to external undersea surroundings. The Upper Eastern Coast of Australia showed the coral bleaching; Northern Sector showed 81\% severe coral bleaching, Central Sector 33\%, and the Southern Sector 1\%. Since Papua New Guinea has 60 active volcanoes, acidic volcanic chemicals $\left(\mathrm{SO}_{2}, \mathrm{H}_{2} \mathrm{~S}, \mathrm{HCl}, \mathrm{HF}, \mathrm{H}_{2} \mathrm{SO}_{4}\right)$ are transported as volcanic plume by current and wind to the Eastern Coast of Australia and may cause the severe coral bleaching. The closer to the Papua New Guinea, the worse the coral bleaching was observed. Therefore, the coral bleaching area is also a prominent drilling site of volcanic seamount black smoker vents. 
Figure 6(b) shows that Eastern CAR is near to the Coastal Range under shallow underthrusting in the subduction zone. Therefore, it is necessary to have several drilling Sites such as 1238, 1239 [16] and dredge locations of 11a, 12, and 13 [19] on the CAR. Such locations may be drilled until artificial vents meet a few of the following criteria;

1) Hydrothermal $\left(\geq 350^{\circ} \mathrm{C}\right)$,

2) Black smoker $\left(\mathrm{FeS} / \mathrm{FeS}_{2}\right)$ venting,

3) Tube Worm Pillar presence,

4) Abundant $\mathrm{H}_{2} \mathrm{~S}$ smelling,

5) Toxic volcanic chemicals $\left(\mathrm{SO}_{2}, \mathrm{H}_{2} \mathrm{~S}, \mathrm{HCl}, \mathrm{HF}, \mathrm{H}_{2} \mathrm{SO}_{4}\right)$ to cause coral bleaching,

6) Lava flow channel. Intervals between volcanic eruptive fissure system can be several hundred meters up to several kilometers with a typical vent field of $30 \times 60 \mathrm{~m}[10]$.

\subsection{Solar Radiation Energy}

The work $(\mathrm{d} W)$ required to move an object a finite distance $(\mathrm{d} x)$ with a thrust force of magnitude $(F)$ is defined as,

$$
\mathrm{d} W=F \mathrm{~d} x
$$

By integration,

$$
\begin{aligned}
\int_{1}^{2} \mathrm{~d} W & =\int_{1}^{2} F \mathrm{~d} x \\
\Delta W & =F \Delta x
\end{aligned}
$$

where $\Delta x=$ length of earth movement by earthquake.

The energy balance for a steady-state process reduces to [21]

$$
\Delta\left(\underline{H}+\frac{u^{2}}{2 g c}+\frac{g Z}{g_{c}}\right)+\underline{Q}-\underline{W}=0
$$

The kinetic energy, $\Delta \frac{u^{2}}{2 g c}$, and the potential energy, $\Delta \frac{g Z}{g_{c}}$, are usually quite small in comparison with the molar enthalpy change, $\Delta \underline{H}$. Therefore, the steady-state energy equation reduces to

$$
\Delta \underline{H}=\underline{Q}-\underline{W}
$$

If molar heat $Q=0$ due to adiabatic process, then,

$$
\begin{gathered}
\Delta \underline{H}=-\underline{W} \\
\therefore \underline{W}=\underline{H_{1}}-\underline{H_{2}} \\
\text { or } \Delta W=\Delta H_{1}-\Delta H_{2}
\end{gathered}
$$

Combining Equations (9) and (12),

$$
\begin{aligned}
& F \Delta x=\Delta H_{1}-\Delta H_{2} \\
& \therefore \Delta x=\frac{\Delta H_{1}-\Delta H_{2}}{F}
\end{aligned}
$$

Equation (13) implies that $\Delta x$ or the effect of an earthquake can be small if 
$\Delta H_{1}$ (enthalpy change before Ecuadorian earthquakes) is lowered down by releasing its enthalpy of volcanic energy through several drillings for hydrothermal vents at the CAR, while $\Delta H_{2}$ (enthalpy change after Ecuadorian earthquake) and thrust force $(F)$ are assumed constant.

Sunlight is composed of 3 processes of reflection, absorption and transmission. As for subaerial volcanoes and submarine seamounts, they absorb the sunlight and convert it into thermal energy with heat transfer medium like magma, lava, air and seawater. Solar radiation energy activates the plate movement to cause earthquakes and volcanic eruptions. Incoming solar radiation is $174 \mathrm{PW}$ and 89 PW absorbed by land and oceans, as shown in Figure 7. Since 71\% of the Earth is surface is the Ocean, $62 \mathrm{PW}$ of solar radiation is available to be $36 \%\{=$ $(62 / 174)(100)\}$ of incoming solar radiation for the Ocean where more than 30,000 submarine volcanic seamounts are present.

The Galapagos Hot Spot (GHS) provides its own thermic energy from magma. Therefore, overall energy at the hot GHS from solar radiation and magma are transferred to the cold CAR according to the second law of thermodynamics.

If the solar energy is $89 \mathrm{PW}, 71 \%$ is ocean and 30,000 seamounts, there are a maximal 2,100 MW per seamount. If 100,000 seamounts; maximal $620 \mathrm{MW}$ per seamount. CAR is a relatively large seamount $(600 \mathrm{~km})$ among seamounts of Chile Rise (2250), Juan Fernandez Ridge (900), Iquique Ridge (600), Nazca Ridge (1000), Malpelo Ridge (300), Coiba Ridge (150), and Cocos Ridge (1000). Even if the solar energy absorbed to the ocean is mostly absorbed to the seawater above CAR, a significant amount of the solar energy is absorbed to the CAR, which moves along with the Nazca Plate relative to the GHS. The CAR stands $1.2 \sim 1.4$ to $2.7 \sim 3.1 \mathrm{~km}$ higher than the surrounding seafloor, and presently is being subducted beneath the Southern American Plate $(5.8 \mathrm{~cm} / \mathrm{yr})$ [4].

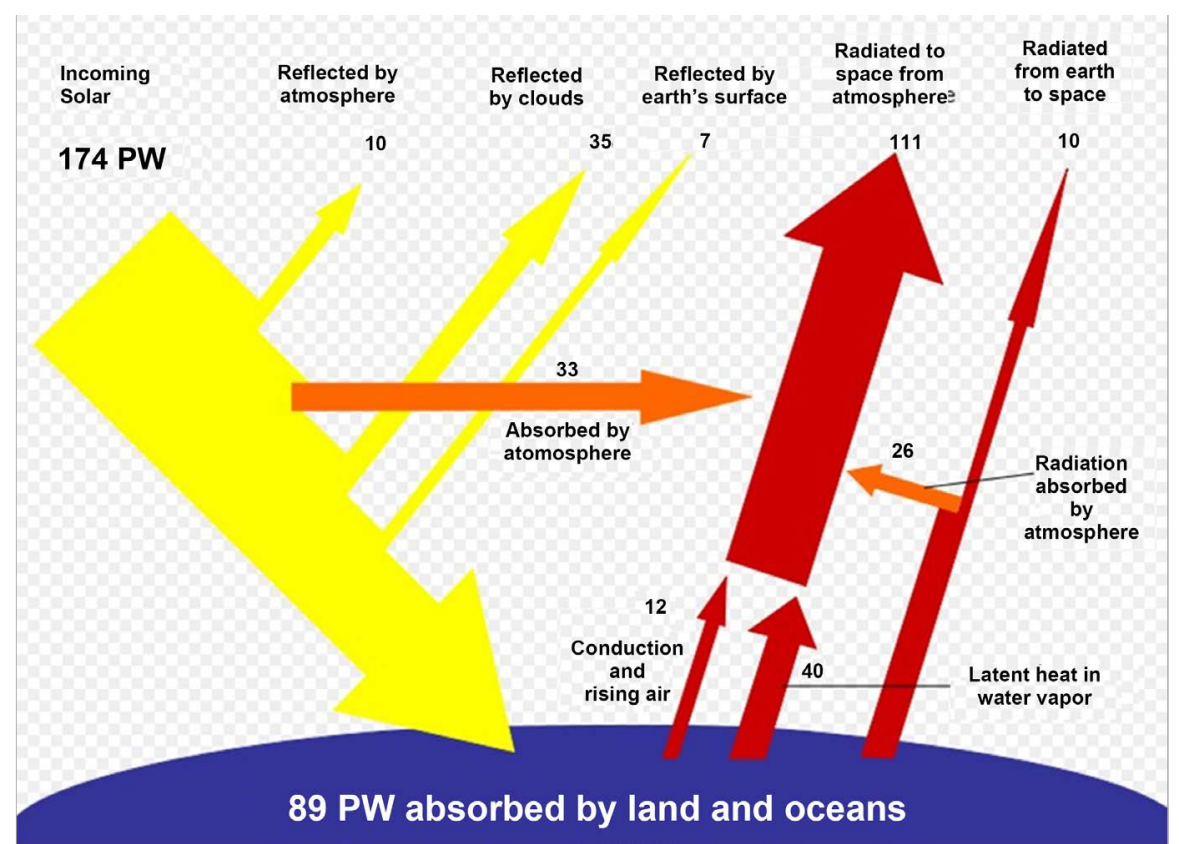

Figure 7. Incoming solar radiation with reflection and absorption in the Earth [13]. 
Therefore, the energy of GHS from solar energy and volcanoes are channeled to the CAR and later landward (Ecuador, Peru, Colombia). Ecuadorian earthquakes occurred on the junction between CAR and the Ecuadorian Continental Shelf (ECS) along with the upper plate crust of the inferred continuation of the CAR. It appears that the Eastern CAR is analogous to a shovel lifting up the South American Plate by subduction, whose force distribution per unit area (pressure) is widely dispersed to the South American Plate along the Peru-Ecuador-Colombia Trench in the form of earthquakes between Trench and Northern Volcanic Zone, as observed in the 1964 Alaska earthquake associated with tectonic deformation between Aleutian the Trench and Aleutian Volcanic Arc [5]. The CAR-Ecuador margin collision length is $160 \mathrm{~km}$ [4]. In order to reduce the Ecuadorian earthquake effects, the thermal energy of the CAR can be released by drilling holes at the Eastern CAR under Pascal's principle. The Hole diameter of Site 1239 was $0.3 \sim 0.4 \mathrm{~m}(11.5 \sim 15$ in) with drilling of core depth from $114 \sim 515 \mathrm{~m}$ [16] until volcanic chemicals $\left(\mathrm{FeS}, \mathrm{FeS}_{2}, \mathrm{H}_{2} \mathrm{~S}\right)$ and hydrother$\mathrm{mal}\left(\geq 350^{\circ} \mathrm{C}\right)$ vents are released $[10]$.

According to the Stefan-Boltzmann law of black body radiation, the total emissive power of a black body $\left(W_{b}\right)$ is proportional to the fourth power of the absolute temperature $(T)[22]$,

$$
W_{b}=0.1713 T^{4}
$$

Therefore, as the solar radiation makes higher $T$, the more emissive power of the CAR is produced.

If a volcano or earthquake is activated by one of 3 types of convergent, divergent and transform plate boundaries, the resultant heat output $(Q)$ from seamounts volcano is,

$$
Q=m C_{p} \Delta T
$$

where $m=$ mass

$$
C_{p}=\text { heat capacity }
$$

$\Delta T=$ temperature difference between before and after volcanoes

If hydrothermal vents are punctured at the CAR, the volcanic energy caused by the volcanic activities in the Galapagos Islands can be slowly released at the CAR-Ecuador margin collision area [9] so that the Ecuadorian earthquake effects are reduced especially in areas of Coastal Cordillera.

Thermal energy, either from Galapagos volcanoes or solar radiation, is delivered to the CAR. Energy is transformed in work while work is converted to force with distance change. Pressure is force per unit area. Therefore, energy is transformed by force per unit area or pressure. Pressure at the interface of the Eastern CAR and Ecuadorian margin is distributed by Pascal's principle of even distribution perpendicularly towards the surface of Eastern CAR, where the earthquake occurs at a certain time at the contact area in weakest Ecuador, Peru and Colombia. It is thus necessary to reduce the energy or pressure inflated in the CAR by drilling holes along the Eastern CAR for hydrothermal vents. 


\subsection{Volcanoes in the GHS and Ecuadorian Earthquake Events}

Table 1 shows volcanoes and earthquake events in Ecuador, Colombia, and Peru from 1977 to 2016, where volcanoes in the GHS and those in the inland are shown in white parts and black shaded parts, respectively. The solar radiation energy in the Galapagos Islands had the highest during one peak value $\left(\sim 30^{\circ} \mathrm{C}\right)$ in the Equator (2 volcanic eruptions in January, 2 in March, 2 in April , 3 in May) and another peak in the Equator (2 in August, 4 in September, 1 in October, 2 in November), as shown in Figure 8. The volcanic energies, together with solar energy in the GHS propagated to the CAR, resulted in Ecuadorian earthquakes with an elapse time of 287 days (Table 2) in the extremely frequent earthquake events (9 times in May), as shown in the monthly solar energy variation at the Equator with dual peaks in Figure 8. It is postulated that frequent volcanic eruptions in September (5 recorded events) were due to the solar radiation energy in the GHS. Ecuadorian earthquake event $(y)$ was dependent upon the volcanic eruptions in the GHS $(x)$ with relationship as, $y=0.47 x+2.79(R=0.32)$ (Figure 9), whose data were obtained from Table 3.

It is evident that there is a dual peak system in the insolation profile with monthly distribution of the Equator ( $0^{\circ}$ latitude), which is similar to the patterns in Figure 8. It is therefore postulated that the volcanic eruption and earthquakes in Ecuador are greatly effected by solar energy due to Ecuadorian location near Equator.

Table 4 shows six cases initiated by volcanic eruptions ("Bing") in the GHS with several "Bang". Therefore, the monitoring of the volcanic eruptions in the GHS at Fernandina (caused 17 inland earthquakes), Sierra Negra (caused 14 earthquakes), and Wolf (caused 7 earthquakes) volcanoes are important for the early warning of Ecuadorian earthquakes. There was only one case of two

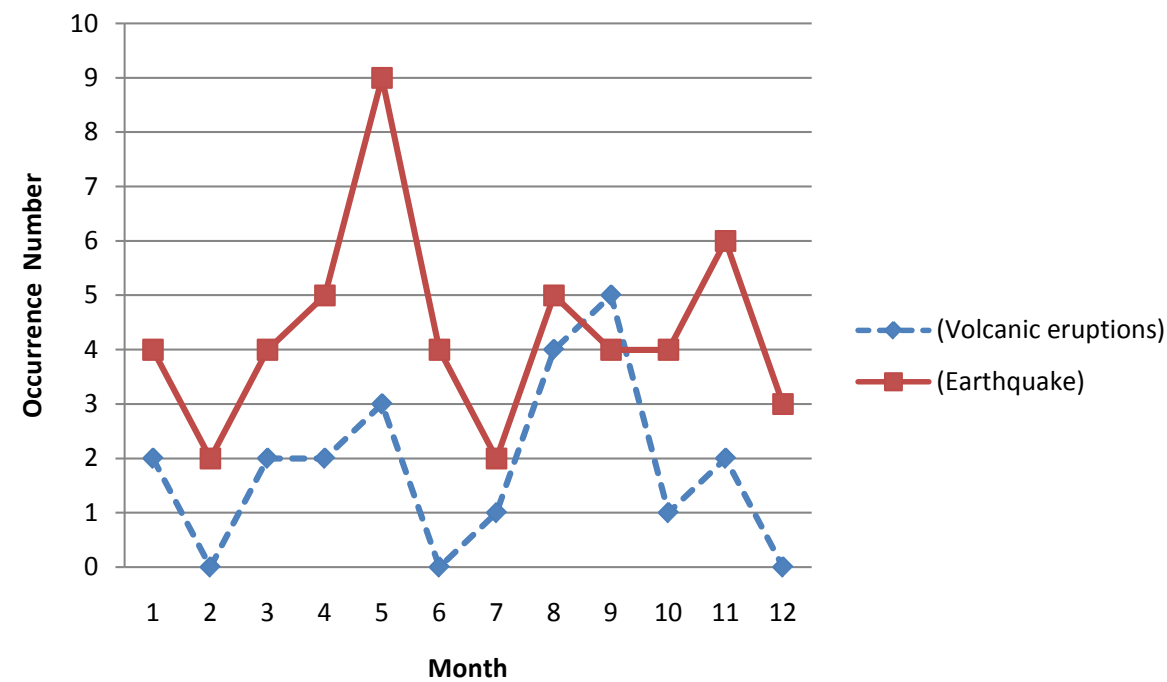

Figure 8. Monthly distributions of the occurrence number of volcano eruptions in the Galapagos Islands and earthquake events in Ecuador, Colombia, and Peru from 1977 to 2016 (data from Table 1 and Table 2). The profiles of volcanic eruptions and earthquakes are similar to dual peaks of monthly solar energy variation at the Equator (Figure 9). 


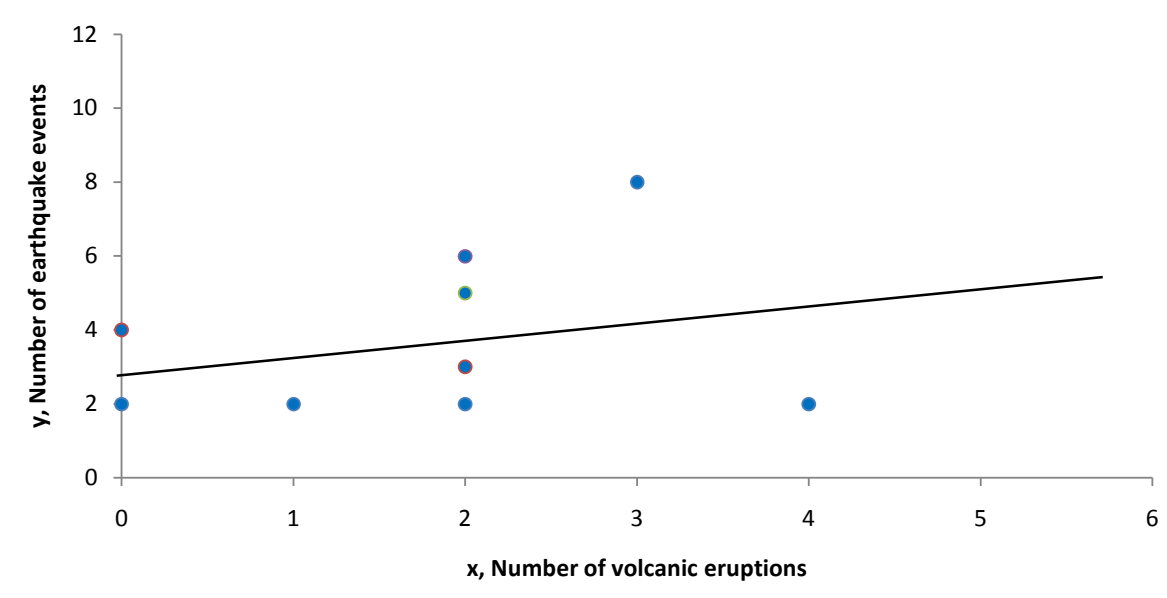

Figure 9. Number of volcanic eruptions $(x)$ in the Galapagos Hot Spot versus number of earthquake events $(y)$ in 24 in Ecuador, 16 in Colombia, and 2 in Peru from 1977 to 2016 with relationship of $y=0.47 x+2.79(R=0.32)$ (data from Table 3 ). Results showed the effect of the volcanic energy $(x)$ impact to the earthquake.

volcanic eruptions with different dates at the same volcano in Wolf causing the same earthquake event \#46.

Since volcanic eruptions in the GHS ("Bing") are not controllable, their thermal energies should be released by drilling holes in the CAR ("Channeling-Cut") for mitigation of Ecuadorian earthquake impacts ("Bang"). In the present study, 38 Ecuadorian earthquakes were caused by 12 Fernandina volcanoes and 12 other Galapagos volcanoes (8 Sierra Negra and 4 Wolf) in the GHS while 14 events were caused by inland Ecuadorian volcanoes including 5 at Guagua Pinchicha, 4 at Sangay, 4 at Reventador, and 1 at Cotopaxi. 16 Colombian earthquakes were initiated 5 times by at Fernanadina, 1 by Cerro Azul, 6 by Sierra Negra, 1 by Wolf, 1 by Marchena, and 2 by Alcedo. 2 Peruvian earthquakes were also initiated by each Wolf and Fernandina. There were 2 earthquakes initiated by Colombian volcanoes Galeras, 1 in Colombia and 1 in Peru, while 1 Peruvian earthquake was caused by Guagua Pichincha. Therefore, 42 earthquakes (76\%) (24 in Ecuador, 16 in Colombia, 2 in Peru) out of 55 events from 1977 to 2016 were initiated by volcanoes in the GHS, especially 17 events by Fernandina (31\%), 14 events by Sierra Negra (25\%), 7 events by Wolf (13\%). It is thus necessary to monitor on-line the volcanic eruptions of Fernandina, Sierra Negra, and Wolf volcanoes in the GHS via satellite with mean elapsed lag time of 287 days (standard deviation \pm 219 ) to provide on early warning system for earthquakes in Ecuador to limit disastrous damage.

\subsection{Drilled Holes for Mitigation of Ecuadorian Earthquake Impacts}

There are three vectors initiating Ecuadorian earthquakes as follows; 1) one from the CAR moving on the subduction interface along the plate boundary, 2) one from Ecuadorian Andes volcanoes, and 3) one from deformation within the South American Plate and the Nazca Plate. The present study suggests that there 
Table 2. List of 6 volcanoes in the GHS and 5 inland volcanoes with corresponding 55 earthquakes in Ecuador (34), Colombia (17), and Peru (4) for the period from 1977 to 2016. Seismic moment energy, Mo (J), was estimated from earthquake magnitude (Mw) (http://alabamaquake.com/energy.html) while the lag time (days) was determined by the date difference between the onsets of volcanic eruption events in the GHS and earthquakes inland. Earthquake energy flow rate $\left(\dot{Q}_{E}\right)\left(\mathrm{J} \cdot \mathrm{d}^{-1}\right)$ was determined from dividing the seismic moment energy (Mo) by the lag time.

\begin{tabular}{|c|c|c|c|c|c|c|c|c|}
\hline \multicolumn{2}{|c|}{ Volcano (Bing) } & \multicolumn{3}{|c|}{ Earthquake (Bang) } & \multirow{2}{*}{$\begin{array}{l}\text { Seismic Moment } \\
\text { Energy Mo (J) }\end{array}$} & \multirow{2}{*}{$\begin{array}{l}\text { Lag time } \\
\text { (days) }\end{array}$} & \multirow{2}{*}{$\begin{array}{c}\text { Country } \\
\text { E (Ecuador), } \\
\text { C (Colombia), } \\
\text { P (Peru) }\end{array}$} & \multirow{2}{*}{$\begin{array}{c}\dot{Q}_{E} \\
\left(\mathrm{~J} \cdot \mathrm{d}^{-1}\right)\end{array}$} \\
\hline Date $(\mathrm{d} / \mathrm{m} / \mathrm{y})$ & Volcano & Event No & Date $(\mathrm{d} / \mathrm{m} / \mathrm{y})$ & $\mathrm{Mw}$ & & & & \\
\hline $23 / 03 / 77$ & Fernandina & 8 & $08 / 05 / 77$ & 5.5 & $2.2 \times 10^{17}$ & 45 & $\mathrm{E}$ & $5.0 \times 10^{15}$ \\
\hline 08/08/78 & Fernandina & 9 & $01 / 03 / 79$ & 5.7 & $4.4 \times 10^{17}$ & 283 & E & $1.6 \times 10^{15}$ \\
\hline $29 / 01 / 79$ & Cerro Azul & 49 & $29 / 05 / 79$ & 5.0 & $3.9 \times 10^{16}$ & 88 & $\mathrm{C}$ & $4.4 \times 10^{14}$ \\
\hline \multirow{12}{*}{$\begin{array}{c}-/ 11 / 79 \\
(2 \text { weeks })\end{array}$} & \multirow{12}{*}{ Sierra Negra } & 50 & $23 / 11 / 79$ & 7.2 & $7.8 \times 10^{19}$ & 15 & $\mathrm{C}$ & $5.2 \times 10^{18}$ \\
\hline & & 10 & $12 / 12 / 79$ & 7.9 & $8.7 \times 10^{20}$ & 42 & E & $2.1 \times 10^{19}$ \\
\hline & & 11 & $26 / 01 / 80$ & 5.6 & $3.1 \times 10^{17}$ & 86 & $\mathrm{C}$ & $3.6 \times 10^{15}$ \\
\hline & & 43 & $20 / 04 / 80$ & 5.2 & $7.8 \times 10^{16}$ & 153 & $\mathrm{E}$ & $5.1 \times 10^{14}$ \\
\hline & & 51 & $25 / 06 / 80$ & 6.0 & $1.2 \times 10^{18}$ & 220 & $\mathrm{C}$ & $5.5 \times 10^{15}$ \\
\hline & & 24 & $18 / 08 / 80$ & 5.9 & $8.7 \times 10^{17}$ & 273 & E & $3.2 \times 10^{15}$ \\
\hline & & 44 & $08 / 10 / 80$ & 6.0 & $1.2 \times 10^{18}$ & 343 & $\mathrm{E}$ & $3.5 \times 10^{15}$ \\
\hline & & 17 & $07 / 07 / 81$ & 5.3 & $1.1 \times 10^{17}$ & 613 & $\mathrm{C}$ & $6.7 \times 10^{14}$ \\
\hline & & 12 & $06 / 05 / 81$ & 6.4 & $4.9 \times 10^{18}$ & 552 & $\mathrm{E}$ & $8.9 \times 10^{15}$ \\
\hline & & 22 & $02 / 01 / 81$ & 5.9 & $8.7 \times 10^{17}$ & 436 & $\mathrm{C}$ & $2.0 \times 10^{15}$ \\
\hline & & 23 & 07/01/81 & 5.9 & $8.7 \times 10^{17}$ & 441 & $\mathrm{C}$ & $2.0 \times 10^{15}$ \\
\hline & & 25 & $27 / 06 / 81$ & 5.3 & $1.1 \times 10^{17}$ & 603 & $\mathrm{E}$ & $1.8 \times 10^{14}$ \\
\hline $01 / 08 / 81$ & Fernandina & 45 & $03 / 11 / 81$ & 5.9 & $8.7 \times 10^{17}$ & 92 & $\mathrm{E}$ & $9.5 \times 10^{15}$ \\
\hline $\begin{array}{l}24 / 05 / 82 \\
06 / 09 / 82\end{array}$ & Wolf & 46 & $18 / 11 / 82$ & 6.5 & $6.9 \times 10^{18}$ & $\begin{array}{l}174 \\
72\end{array}$ & $\mathrm{E}$ & $\begin{array}{l}4.0 \times 10^{16} \\
9.6 \times 10^{15}\end{array}$ \\
\hline \multirow[t]{2}{*}{$\begin{array}{c}-/ 3-9 / 82 \\
\text { (6 months) }\end{array}$} & Guagua Pichincha & 37 & $11 / 04 / 82$ & 5.1 & $5.5 \times 10^{16}$ & - & $\mathrm{E}$ & - \\
\hline & & 41 & $31 / 03 / 83$ & 5.6 & $3.1 \times 10^{17}$ & 204 & $\mathrm{C}$ & $1.5 \times 10^{15}$ \\
\hline \multirow[t]{2}{*}{$06 / 09 / 82$} & Wolf & 47 & $12 / 04 / 83$ & 7.0 & $3.9 \times 10^{19}$ & 216 & $\mathrm{P}$ & $1.8 \times 10^{17}$ \\
\hline & & 27 & $19 / 05 / 83$ & 5.2 & $7.8 \times 10^{16}$ & 253 & $\mathrm{E}$ & $3.1 \times 10^{14}$ \\
\hline $05 / 08 / 83$ & Sangay & 34 & $17 / 01 / 84$ & 5.5 & $2.2 \times 10^{17}$ & - & $\mathrm{E}$ & - \\
\hline $30 / 03 / 84$ & Fernandina & 13 & $10 / 06 / 85$ & 5.5 & $2.2 \times 10^{17}$ & 430 & $\mathrm{C}$ & $5.1 \times 10^{14}$ \\
\hline \multirow{4}{*}{$-/-/ 87$} & \multirow{4}{*}{ Reventador } & 28 & & 5.2 & $7.8 \times 10^{16}$ & - & $\mathrm{E}$ & - \\
\hline & & 29 & $06 / 03 / 87$ & 6.4 & $4.9 \times 10^{18}$ & - & $\mathrm{E}$ & - \\
\hline & & 30 & & 7.1 & $5.5 \times 10^{19}$ & - & $\mathrm{E}$ & - \\
\hline & & 32 & $22 / 09 / 87$ & 6.0 & $1.2 \times 10^{18}$ & - & $\mathrm{E}$ & - \\
\hline \multirow{3}{*}{$14 / 09 / 88$} & & 18 & $12 / 02 / 89$ & 5.1 & $5.5 \times 10^{16}$ & 148 & $\mathrm{C}$ & $3.7 \times 10^{14}$ \\
\hline & Fernandina & 19 & 09/09/89 & 5.7 & $4.4 \times 10^{17}$ & 207 & $\mathrm{C}$ & $2.1 \times 10^{15}$ \\
\hline & & 31 & $11 / 08 / 90$ & 5.1 & $5.5 \times 10^{16}$ & 697 & E & $7.9 \times 10^{13}$ \\
\hline
\end{tabular}




\begin{tabular}{|c|c|c|c|c|c|c|c|c|}
\hline & & 15 & $02 / 09 / 90$ & 6.2 & $2.5 \times 10^{18}$ & 718 & $\mathrm{E}$ & $3.5 \times 10^{15}$ \\
\hline \multirow{3}{*}{$14 / 09 / 88$} & & 26 & $10 / 02 / 90$ & 5.5 & $2.2 \times 10^{17}$ & 408 & $\mathrm{E}$ & $5.4 \times 10^{14}$ \\
\hline & Гетाлапाпाа & 14 & $25 / 08 / 90$ & 5.3 & $1.1 \times 10^{17}$ & 712 & $\mathrm{C}$ & $1.5 \times 10^{14}$ \\
\hline & & 35 & $29 / 07 / 90$ & 5.2 & $7.8 \times 10^{16}$ & 751 & $\mathrm{P}$ & $1.0 \times 10^{14}$ \\
\hline $19 / 04 / 91$ & Fernandina & 33 & $26 / 12 / 92$ & 5.4 & $1.6 \times 10^{17}$ & 612 & $\mathrm{E}$ & $2.6 \times 10^{14}$ \\
\hline $25 / 09 / 91$ & Marchena & 16 & $19 / 11 / 91$ & 7.2 & $7.8 \times 10^{19}$ & 54 & $\mathrm{C}$ & $1.4 \times 10^{18}$ \\
\hline$-/ 07 / 92$ & Galeras & 52 & $15 / 08 / 92$ & 5.9 & $8.7 \times 10^{17}$ & - & $\mathrm{C}$ & - \\
\hline$-/-1-/ 90$ & Guagua Pichincha & 36 & $29 / 03 / 91$ & 5.6 & $3.1 \times 10^{17}$ & - & $\mathrm{P}$ & - \\
\hline $14 / 01 / 93$ & Galeras & 48 & $11 / 09 / 93$ & 5.7 & $4.4 \times 10^{17}$ & - & $\mathrm{P}$ & $1.9 \times 10^{15}$ \\
\hline \multirow{3}{*}{$15 / 11 / 93$} & Aloods & 42 & $06 / 06 / 94$ & 6.8 & $2.0 \times 10^{19}$ & 201 & $\mathrm{C}$ & $1.0 \times 10^{17}$ \\
\hline & & 20 & $26 / 11 / 94$ & 5.3 & $1.1 \times 10^{17}$ & 376 & $\mathrm{C}$ & $2.9 \times 10^{14}$ \\
\hline & & 38 & $03 / 10 / 95$ & 7.0 & $3.9 \times 10^{19}$ & - & $\mathrm{E}$ & - \\
\hline \multirow[t]{2}{*}{$-/-/ 95$} & Sangay & 39 & $03 / 10 / 95$ & 6.4 & $4.9 \times 10^{18}$ & - & $\mathrm{E}$ & - \\
\hline & & 40 & 08/10/95 & 5.4 & $1.6 \times 10^{17}$ & - & $\mathrm{E}$ & - \\
\hline $25 / 01 / 95$ & Fernandina & 21 & $13 / 11 / 95$ & 5.3 & $1.1 \times 10^{17}$ & 288 & $\mathrm{C}$ & $3.8 \times 10^{14}$ \\
\hline $13 / 05 / 05$ & Fernandina & - & $21 / 05 / 05$ & 6.3 & $3.5 \times 10^{18}$ & 8 & $\mathrm{E}$ & $4.4 \times 10^{17}$ \\
\hline \multirow{2}{*}{$22 / 10 / 05$} & Sirm Norm & - & $23 / 12 / 05$ & 6.1 & $1.7 \times 10^{18}$ & 60 & $\mathrm{E}$ & $2.8 \times 10^{16}$ \\
\hline & Sierra Negra & - & $21 / 05 / 06$ & 6.0 & $1.2 \times 10^{18}$ & 210 & $\mathrm{E}$ & $5.7 \times 10^{15}$ \\
\hline \multirow{3}{*}{$10 / 04 / 09$} & & $\begin{array}{l}\text { Galapagos } \\
\text { Islands }\end{array}$ & $15 / 04 / 09$ & 6.3 & $3.5 \times 10^{18}$ & 5 & $\mathrm{E}$ & $7.0 \times 10^{17}$ \\
\hline & Fernandina & - & $10 / 05 / 09$ & 6.1 & $1.7 \times 10^{18}$ & 30 & $\mathrm{E}$ & $5.7 \times 10^{16}$ \\
\hline & & $\begin{array}{l}\text { Galapagos } \\
\text { Islands }\end{array}$ & $15 / 10 / 09$ & 6.0 & $1.2 \times 10^{18}$ & 185 & $\mathrm{E}$ & $6.5 \times 10^{15}$ \\
\hline \multirow{3}{*}{$25 / 05 / 15$} & & $\begin{array}{l}\text { Muisne, } \\
\text { Pedernales }\end{array}$ & $16 / 04 / 16$ & 7.8 & $6.2 \times 10^{20}$ & 321 & $\mathrm{E}$ & $1.9 \times 10^{18}$ \\
\hline & Wolf & Rosa Zarate & $18 / 05 / 16$ & 6.7 & $1.4 \times 10^{19}$ & 358 & $\mathrm{E}$ & $3.9 \times 10^{16}$ \\
\hline & & Mompiche & $19 / 05 / 16$ & 6.8 & $2.0 \times 10^{19}$ & 359 & $\mathrm{E}$ & $5.6 \times 10^{16}$ \\
\hline $14 / 08 / 15$ & Cotopaxi & - & - & - & - & - & $\mathrm{E}$ & - \\
\hline
\end{tabular}

is an additional vector to initiate Ecuadorian earthquakes due to the volcanic eruptions in the GHS through the CAR. Since $76 \%$ of earthquakes were initiated by volcanic eruptions in the GHS ("Bing"), it is necessary to release the propagated energy in the CAR ("Channeling") through drilled Holes ("Cut") to mitigte the impact of Ecuadorian earthquakes ("Bang"). The eruption at Wolf in the GHS (25 May 2015) might induce the inland Cotopaxi eruption within 79 days. After Wolf in the GHS and 242 days after the Cotopaxi eruption, a disastrous earthquake ( $\mathrm{Mw} 7.8$ ) occurred at Muisne and Pedernales $\left(0.371^{\circ} \mathrm{N}\right.$ $79.940^{\circ} \mathrm{W}$, the boundary of Esmeraldas terraces and Coastal cordillera) on April 15, 2016. Thereafter, two consecutive earthquake events at coastal towns of Rosa Zarate (Mw 6.7) and Mompiche (Mw 6.8) occurred after 32 and 33 days, respectively (Table 2). The consecutive transfer of thermal energy from the GHS 
Table 3. Monthly distributions of the number of volcanic eruptions in the Galapagos Hot Spot and the number of earthquake events in-land from 1977 and 2016 (data from Table $2)$.

\begin{tabular}{ccc}
\hline Month & Number of volcanic eruption & Number of earthquake event \\
\hline 1 & 3 & 4 \\
2 & 0 & 2 \\
3 & 2 & 4 \\
4 & 2 & 5 \\
5 & 3 & 9 \\
6 & 0 & 4 \\
7 & 1 & 2 \\
8 & 4 & 5 \\
9 & 5 & 4 \\
10 & 1 & 4 \\
11 & 2 & 6 \\
12 & 0 & 3 \\
\hline
\end{tabular}

Table 4. Various modes of volcanic eruptions in the GHS with corresponding earthquake events inland of Ecuador, Colombia, and Peru.

\begin{tabular}{cccc}
\hline $\begin{array}{c}\text { Number of } \\
\text { Volcanic Eruption }\end{array}$ & $\begin{array}{c}\text { Number of Earthquake } \\
\text { per Case }\end{array}$ & $\begin{array}{c}\text { Number of } \\
\text { Cases }\end{array}$ & Earthquake Event Number \\
\hline 1 & 1 & 9 & $8,9,49,45,13,33,16,21,21 / 05 / 05$ \\
1 & 2 & 2 & $42,20,23 / 12 / 05,21 / 05 / 06$ \\
1 & 3 & 3 & $41,47,27,15 / 04 / 09,10 / 05 / 09,15 / 10 / 09$, \\
1 & 7 & 1 & $16 / 04 / 16,18 / 05 / 16,19 / 05 / 16$ \\
1 & 12 & 1 & $18,19,31,15,26,14,35$ \\
2 & 1 & 1 & $12,22,23,25$ \\
& & & $40,10,11,43,51,24,44,17$, \\
\end{tabular}

("Bing") to Ecuador ("Bang") should be mitigated by releasing the volcanic energy reserved in the CAR ("Channeling") through drilled Holes ("Cut") in the CAR-Ecuador margin collision length of $160 \mathrm{~km} \mathrm{[8].} \mathrm{The} \mathrm{lag} \mathrm{time} \tau$, is simply the time needed for a particle of fluid to flow from the entrance to the exit of the pipe defined as [23],

$$
\tau=\frac{\text { volume of pipe }}{\text { volumetric flow rate }}
$$

or

$$
\tau=\frac{A L}{q}
$$

where $L$ is the distance between the GHS and Ecuador $(926 \mathrm{~km})$,

$A$, the cross-sectional area of the CAR $(160 \mathrm{~km} \times 2.5 \mathrm{~km}), 160 \mathrm{~km}$ collision 
length [8] $\times 2.5 \mathrm{~km}$ depth $(=3500 \mathrm{~m}-1000 \mathrm{~m})$ [16],

$\tau$, the lag time $287 \pm 219$ days from Table 2, ranging from one case of 8 days for the earthquake event which occurred on May 12, 2005 to another case of 751 days for the event \#35.

There were 42 earthquakes initiated by volcanic eruptions in the GHS; 24 in Ecuador, 16 in Colombia, and 2 in Peru. Since the inland earthquakes occurred after 287 days of volcanic eruptions in the GHS through channeling the CAR, the volumetric flow rate $(q)$ is given by,

$$
q=\frac{A L}{\tau}=\frac{(160 \times 2.5 \times 926) \mathrm{km}^{3}}{287 \text { days }}=1.3 \times 10^{3} \mathrm{~km}^{3} \cdot \mathrm{d}^{-1}
$$

Assuming the density of the volcanic materials to be $10^{3} \mathrm{~kg} \mathrm{~m}^{-3}$, then the mass flow rate $(\dot{m})$ is,

$$
\dot{m}=1.3 \times 10^{12} \text { ton } \cdot \mathrm{d}^{-1}
$$

Since the volcanic energy flow rate from the GHS $\left(\dot{Q}_{G}\right)$ is given by,

$$
\dot{Q}_{G}=\dot{m} C_{P} T i
$$

where $C_{P}$ is the specific heat at constant pressure $\left(1 \mathrm{cal} \cdot \mathrm{g}^{-1} \cdot \mathrm{c}^{-1}\right)$,

$T i$ is the temperature of the volcanic material $\left(350^{\circ} \mathrm{C}\right)[10]$.

Therefore, $\dot{Q}_{G}$ is given by,

$$
\begin{aligned}
\dot{Q}_{G} & =\left(1.3 \times 10^{12} \mathrm{ton} \cdot \mathrm{d}^{-1}\right) \times\left(1 \mathrm{cal} \cdot \mathrm{g}^{-1} \cdot{ }^{\circ} \mathrm{C}^{-1}\right) \times\left(350^{\circ} \mathrm{C}\right) \\
& =4.6 \times 10^{20} \mathrm{cal} \cdot \mathrm{d}^{-1}
\end{aligned}
$$

or

$$
\dot{Q}_{G}=1.9 \times 10^{21} \mathrm{~J} \cdot \mathrm{d}^{-1}
$$

As shown in Table 2, the highest energy flow rate of Ecuadorian earthquakes $\left(\dot{Q}_{E}\right)$ from 1977 to 2016 was $2.1 \times 10^{19} \mathrm{~J} \cdot \mathrm{d}^{-1}$ for event \#10 with Mw 7.9, which was far less $(1 \%)$ than $\dot{Q}_{G}=1.9 \times 10^{21} \mathrm{~J} \cdot \mathrm{d}^{-1}$.

Since the mean lag time was 287 days,

$$
Q_{G}=\left(1.9 \times 10^{21} \mathrm{~J} \cdot \mathrm{d}^{-1}\right) \times(287 \text { days })=5.5 \times 10^{23} \mathrm{~J}
$$

From the conversion of earthquake magnitude to seismic momentum energy (Mo), $Q_{G}$ of $5.5 \times 10^{23} \mathrm{~J}$ is equivalent to Mo of $5.5 \times 10^{23} \mathrm{~J}[15]$.

The moment magnitude scale $(\mathrm{Mw})$ among Richter magnitude scale $\left(M_{L}\right)$ and surface wave magnitude scale $\left(M_{S}\right)$ is determined by the relationship of $\mathrm{Mw}=\frac{2}{3} \log _{10}(\mathrm{Mo})-10.7$ with the seismic moment $(\mathrm{Mo})$ in $\operatorname{erg}\left(10^{-7} \mathrm{~N} \cdot \mathrm{m}\right)$.

Therefore, $Q_{G}$ is equivalent to $\mathrm{Mw}$ 9.79; regarded as the maximum transferrable energy through the CAR.

However, the strongest earthquake in the world was Mw 9.5, which occurred in southern Chile in 1960. There were big earthquakes in 1906 (Mw 8.8), 1942 (Mw 7.8), 1958 (Mw 7.8), 1960 (Mw 7.6), 1970 (Mw 7.8) 1979 (Mw 8.1), 1996 (Mw 7.5) (Bilek 2009), and 2016 (Mw 7.8) along the coastal seashores of Ecuador, 
which were all less than $\mathrm{Mw}$ 9.79. $\dot{Q}_{E}$ for each earthquake event was determined from Mo ( $\mathrm{J}$ ) divided by the lag time (days), as summarized in Table 2. $\dot{Q}_{G}$ means the maximum transferrable volcanic energy flow rate from the GHS to Ecuador through the channel of the CAR. Therefore, the more release of hydrothermal energy in the CAR $\left(\dot{Q}_{H}\right)$ could induce the less impacts of Ecuadorian earthquakes $\left(\dot{Q}_{E}\right)$. The hydrothermal energy flow rate $\left(\dot{Q}_{H}\right)$ from each drilled Hole $(i)$ is,

$$
\begin{gathered}
\dot{Q}_{i}=\dot{m} C_{p} \Delta T_{i} \\
T_{\text {exit }}=350^{\circ} \mathrm{C} \quad[10] \\
C_{p}=4.2 \mathrm{~J} \cdot \mathrm{g}^{-1} \cdot{ }^{\circ} \mathrm{C}^{-1} \\
\dot{m}=\rho \cdot u \cdot s \\
D=0.3 \sim 0.4 \mathrm{~m} \quad[16] \\
\therefore S=\frac{\pi}{4} D^{2}=\frac{\pi}{4} \cdot 0.4^{2} \mathrm{~m}^{2}
\end{gathered}
$$

The total number of holes $(n)$ required to mitigate the impact of Ecuadorian earthquakes determined, for example, for the equivalent case of earthquake event number 8 in Table $2,\left(\dot{Q}_{E}\right)$, as $5 \times 10^{15} \mathrm{~J} \cdot \mathrm{d}^{-1}$, converted to,

$$
\begin{aligned}
& \left(5 \times 10^{15} \mathrm{~J} \cdot \mathrm{d}^{-1}\right) \times\left(1 \mathrm{~d} \cdot 24 \mathrm{~h}^{-1}\right) \times\left(1 \mathrm{~h} \cdot 3600 \mathrm{~s}^{-1}\right) \\
& =(n) \times\left(\rho, 1 \mathrm{~g} \cdot 10^{6} \mathrm{~m}^{-3}\right) \times\left(u, \mathrm{~m} \cdot \mathrm{s}^{-1}\right) \times\left(\frac{\pi}{4} \cdot 0.16 \mathrm{~m}^{2}\right) \times\left(4.2 \mathrm{~J} \cdot \mathrm{g}^{-1} \cdot{ }^{\circ} \mathrm{C}^{-1}\right) \times\left(350^{\circ} \mathrm{C}\right)
\end{aligned}
$$

Thus,

$$
n=\frac{2.3 \times 10^{12}}{u}
$$

where $u\left(\mathrm{~m} \cdot \mathrm{s}^{-1}\right)$ is the exit linear velocity of hydrothermal energy $\left(\dot{Q}_{H}\right)$ from drilled Hole.

Since Kilauea Volcano in Hawaii showed channel velocities of $1 \sim 3 \mathrm{~m} \cdot \mathrm{s}^{-1}$ [24] to be approximated as $2.3 \mathrm{~m} \cdot \mathrm{s}^{-1}$, then

$$
n \cong 1 \times 10^{12}
$$

Therefore, an almost infinite number of drilling holes $\left(n=1 \times 10^{12}\right)$ is required to entirely negate the impact of Ecuadorian earthquakes by event \#8. In order to minimize the harmful effects of Ecuadorian earthquakes ("Bang"), the volcanic thermal energy from the GHS ("Bing") was released through drilled Holes at the CAR ("Channeling-Cut"). When drilled Holes are present in the CAR, the volcanic energy from the volcanic eruption in the GHS is no longer reserved in the CAR, but released to the seawater of the Ecuadorian Trench through drilled Holes around the contour of $2500 \mathrm{~m}$ in depth (Figure 6(a)). Since the CAR shares its geological origin with the Galapagos Islands [12], the resonance is expected between the GHS and the CAR, so that volcanic energy from the GHS is amplified in the CAR due to the constructive interference during volcanic eruptions to cause the increased earthquake magnitude. Further- 
more, the marine terraces on the Ecuadorian coast with Pliocene sediments [7] cause oscillatory behavior of enhanced earthquake frequency with activated energy followed by the Planck-Einstein relation [25]. Therefore, a reduced number of drilled Holes $(n)$ than $1 \times 10^{12}$ may be required if the impulse input of volcanic energy from the GHS is continuously released to the Ecuadorian Trench through 20 to 80 drilled Holes in the northeastern CAR. Since there are less accumulated net energies from 1) volcanic energy in the GHS, 2) resonant energy with similar materials of the CAR, and 3) solar radiation energy over the CAR, the inland Ecuadorian earthquakes are mitigated by less oscillatory behaviors in the northeastern Tablazos.

The monthly profile of volcanic eruptions was similar to that of earthquake events (Figure 8). The number of volcanic eruptions $(x)$ were plotted with respect to number of earthquake events $(y)$ to see the linear relationship of $y=$ $0.47 x+2.79, R=0.32$ (Figure 9). It was possible to provide an early-warning to prepare for Ecuadorian earthquakes which were induced by volcanic eruptions in the GHS with the lag time ranging from 8 to 751 days, mean \pm standard deviation of $287 \pm 219$ days (Table 2 ).

The national geological map of Ecuador shows the marine terraces composed of mainly Tertiary, partially Cretaceous, and Quaternary sedimentary rocks [26]. Since the CAR shares the geological characteristics of the GHS [27], the volcanic energy in the GHS is amplified in the CAR due to the principle of resonance between similar materials under constructive interference [25] to be propagated to Ecuador as enhanced earthquakes. Furthermore, oscillatory behavior by Ecuadorian Pliocene sediments of marine terraces (Tablazos) for a unit-impulse forcing function of volcanic eruption in the GHS is expressed by Newton's law of motion [23] as,

$$
\frac{W}{g_{c}} \frac{\mathrm{d}^{2} Y}{\mathrm{~d} t^{2}}=-K Y-C \frac{\mathrm{d} Y}{\mathrm{~d} t}+F(t)
$$

where

$Y(t)$ is the travel distance variable with time $(t)$,

$K$, the Hooke's constant of the CAR,

$C$, the viscous damping coefficient of Pliocene sediments at Ecuadorian marine terraces

(Tablazos),

$F(t)$, the driving force of the Ecuadorian earthquake,

$W$, the mass of Ecuador,

$g_{c}$, the gravitational constant.

3 cases of 1 ) oscillatory $(\zeta<1), 2$ ) critically damped ( $\zeta=1)$, and 3) nonoscillatory $(\zeta>1)$ solutions are available, where the damping ratio $(\zeta)$ is given by,

$$
\zeta=\sqrt{\frac{g_{c} C^{2}}{4 W K}}
$$

Since $g_{c}, W$, and $K$ are constant, $\zeta$ is proportional to $C$ of Tablazos and less than 1 [23] to be oscillatory. The freguency propagated from the CAR is in- 
creased due to oscillatory behavior of Tablazos in Ecuador. Damping ratios of Tertiary and Quaternary were less than 20\% in seismic response [28]. Therefore, the Ecuadorian earthquakes occurring at marine terraces have been large earthquakes in Tablazos; 1906 (M 8.8), 1942 (Mw 7.8), 1958 (M 7.8), 1960 (Mw 7.6), 1970 (M 7.8), 1979 (Mw 8.1), 1996 (Mw 7.5) [29], and 2016 (Mw 7.8). Volcanic energies from the GHS propagate through the CAR to Ecuadorian Tablazos in the form of enhanced oscillatory earthquakes for strong damage. Besides, the subduction of the Nazca plate beneath the South American plate proceeds with a $\mathrm{N} 90^{\circ} \mathrm{E}$ convergence and a rate of $8 \mathrm{~cm} \cdot \mathrm{year}^{-1}$ [8]. Furthermore, major earthquakes shook northwestern Ecuador and southwestern Colombia so that the Esmeraldas and Manta terraces in northwestern Ecuador were considered as an area of high seismic risk [30]. It was thus recommended to drill hydrothermal vents at the CAR in front of areas between the Esmeraldas and Manta terraces.

Specifically, more drilled holes can be allocated in the northeastern CAR to block the propagation of volcanic energy from the GHS toward the Esmeraldas area to reduce the impact of Ecuadorian earthquakes.

For the sake of simplicity, Ecuadorian earthquakes could be mitigated by releasing the volcanic energy through the enlarged Holes of Site 1239 (A, B, C) with the highly productive upwelling chlorophyll system at the northeastern CAR.

\subsection{Similar Cases of Bing-Bang-Channeling-Cut Mechanism}

Table 5 shows the relative similar cases for the mechanism of Bing-Bang-Channeling-Cut in Japan, California (USA), Chile, Peru, Mexico, and Italy. Each case consists of Bing, Bang, Chaneling, and Cut. Similar technology of Cut described in the present study can be hypothetically applicable to each case to reduce the impact of Bing to Bang through Channeling.

\section{Conclusions}

The mechanism of "Bing-Bang-Channeling-Cut" was proposed to reduce the volcanic energy ("Bing") from the Galapagos Hot Spot (GHS) to limit the damage from Ecuadorian earthquakes ("Bang"). The lag time between the volcanic eruption and Ecuadorian earthquake was presumably caused by the volcanic seamounts of the Carnegie Ridge ("Channeling"). Similar cases could be applicable to Japan, California (USA), Chile, Peru, Mexico, and Italy. Experimental results from the water reservoir showed that the lag time decreased when increasing drilled holes ("Cut") in the bottom of the reservoir. 6 volcanoes in the GHS induced 42 inland earthquakes (24 in Ecuador, 16 in Colombia, 2 in Peru) out of 55 from 1977 to 2016 . Earthquake was hypothetically initiated by volcanoes in the GHS, especially 17 events caused by Fernandina (31\%), 14 events by Sierra Negra (25\%), 7 events by Wolf (13\%). Volcanic eruptions in September in the GHS caused the Ecuadorian earthquakes subsequently in May with a lag time \pm standard deviation of 287 days $( \pm 219)$. 
Table 5. The relative similar hypothetical cases for the mechanism of Bing-Bang-Channeling-Cut in the world.

\begin{tabular}{|c|c|c|c|c|}
\hline No. & Bing & Bang & Channeling & Cut \\
\hline 1 & Galapagos Hot Spot & Ecuador & Carnegie Ridge & $\begin{array}{l}\text { North East Carnegie Ridge with } \\
\text { Ecuador Trench }\end{array}$ \\
\hline 2 & $\begin{array}{l}\text { 1) Anatahan, Mariana Islands } \\
\text { 2) Oshika Peninsula of Tohoku } \\
\text { 3) Subduction of Philippine Sea } \\
\text { Plate or Pacific Plate }\end{array}$ & $\begin{array}{l}\text { 1) Izu Oshima, Izu Peninsula, } \\
\text { Izu Islands, Bonin Islands, Japan } \\
\text { 2) Tohoku } \\
\text { 3) Kobe }\end{array}$ & $\begin{array}{l}\text { 1) East/West Mariana } \\
\text { Ridge, Bonin Islands, } \\
\text { Izu Islands } \\
\text { 2) Shatsky Rise } \\
\text { 3) Izu-Shichito Ridge }\end{array}$ & $\begin{array}{l}\text { 1) Izu Arc, Bonin Arc with Izu-Bonin } \\
\text { Trench, Mariana Arc with Mariana } \\
\text { Trench } \\
\text { 2) Shatsky Rise with Japan Trench } \\
\text { 3) Izu-Shichito Ridge with Nankai } \\
\text { Trough }\end{array}$ \\
\hline 3 & $\begin{array}{l}\text { Murray, Mendocino, Blanco } \\
\text { Fracture Zone }\end{array}$ & $\begin{array}{l}\text { San Andreas Fault, Inner } \\
\text { Borderland, Outer Borderland, } \\
\text { Southern Borderland } \\
\text { (California, U. S. A) }\end{array}$ & $\begin{array}{l}\text { Explorer Ridge, } \\
\text { Juan de Fuca Ridge, } \\
\text { Gorda Ridge }\end{array}$ & $\begin{array}{l}\text { Cascadia Subduction Zone with Pacific } \\
\text { Northwest }\end{array}$ \\
\hline 4 & Mt. Erebus & Chile & $\begin{array}{l}\text { Iquique Ridge, } \\
\text { Juan-Fernandez Ridge }\end{array}$ & $\begin{array}{l}\text { Iquique Ridge, Juan-Fernandez Ridge } \\
\text { with Chile Trench }\end{array}$ \\
\hline 5 & Mt. Erebus & Peru & Nazca Ridge & Nazca Ridge with Peru Trench \\
\hline 6 & Easter Island & Mexico & East Pacific Rise (EPR) & $\begin{array}{l}14 \text { high temperature }\left(\geq 350^{\circ} \mathrm{C}\right) \\
\text { hydrothermal vents and low } \\
\text { temperature }<35^{\circ} \mathrm{C} \text { biological } \\
\text { communities along the EPR axis }\end{array}$ \\
\hline 7 & Mt. Etna & Italy (Sicilia, Naples, L'Aguila) & Marsili & Campi Flegrei/Solfatara \\
\hline
\end{tabular}

The present study showed that there was an additional vector initiating the Ecuadorian earthquakes caused by the volcanic eruption in the GHS through the Carnegie Ridge (CAR). It was found that the impact of Ecuadorian earthquakes could be mitigated by releasing the volcanic energy through the enlarged exit diameters in Holes of Site 1239 (A, B, C) with the presently productive upwelling chlorophyll system at the northeastern CAR.

\section{Acknowledgements}

The author wishes to express his great appreciation of the assistance provided by the late Professor Emeritus Soon-Ung Park at The School of Earth and Environmental Sciences of Seoul National University. This work was funded by the Faculty of Graduate Studies and Research at the University of Suwon and G-LAND, Republic of Korea. Editing work undertaken by Professor Jonathan Wright is also greatly appreciated.

\section{Conflicts of Interest}

The authors declare no conflicts of interest regarding the publication of this paper.

\section{References}

[1] Geophysical Institute of the National Polytechnic School (2014) National Seismology and Volcanology Service. http://www.igepn.edu.ec

[2] MacDonald, K. (2010) What Is a Hotspot. NOAA Ocean Explorer. https://oceanexplorer.noaa.gov>hotspots 
[3] Pedoja, K., Dumont, J.F., Lamothe, M., Ortlieb, L., Collot, J.-Y., Ghaleb, B., Auclair, M., Alvarez, V. and Labrousse, B. (2006) Plio-Quarternary Uplift of the Manta Peninsula and La Plata Island and the Subduction of the Carnegie Ridge, Central Coast of Ecuador. Journal of South American Earth Sciences, 22, 1-21. https://doi.org/10.1016/j.jsames.2006.08.003

[4] Pazmino, N. and Gomez, H. (2008) The Galapagos Islands: The Rights of the Fragile Environment in the Law of the Sea and Their Potential Outer Limits of the Continental Shelf beyond 200 Nautical Miles. NAPM, Ecuadorian Chamber of the Law of the Sea.

[5] Plafker, G. (1971) The Alaskan Earthquake of 1964 and Chilean Earthquake of 1960: Implications for Arc Tectonics. Ph.D. Thesis, Stanford University, Palo Alto, California.

[6] Somoza, R. (2002) Paleomagnetism in the Precordillera of Northern Chile (22 30 'S): Implications for the History of Tectonic Rotations in the Central Andes. Earth and Planetary Science Letters, 194, 369-381. https://doi.org/10.1016/S0012-821X(01)00548-9

[7] DeVries, T.J. (1988) The Geology of Late Cenozoic Marine Terraces (Tablazos) in Northwestern Peru. Journal of South American East Sciences, 1, 121-136. https://doi.org/10.1016/0895-9811(88)90030-2

[8] Michaud, F., Witt, C. and Royer, J.-Y. (2009) Influence of the Subduction of the Carnegie Volcanic Ridge on Ecuadorian Geology: Reality and Fiction. Geological Society of America, 204, 217-228. https://doi.org/10.1130/2009.1204(10)

[9] Gutscher, M.-A., Malavielle, J., Lallemand, S. and Collot, J.-Y. (1999) Tectonic Segmentation of the North Andean Margin Impact of the Carnegie Ridge Collision. Earth and Plenetary Science Letters, 168, 255-270. https://doi.org/10.1016/S0012-821X(99)00060-6

[10] Fornari, D., Tivey, M., Schouten, H., Perfit, M., Yoerger, D., Bradley, A., Edwards, M., Haymon, R., Scheirer, D., Damm, K.V., Shank, T. and Soule, A. (2004) Submarine Lava Flow Emplacement at the East Pacific Rise $9^{\circ} 50^{\prime} \mathrm{N}$ : Implications for Uppermost Ocean Crust Stratigraphy and Hydrothermal Fluid Circulation. Geophysical Monograph, 148, 187-218.

[11] Solar Gis (2014) https://solargis.com/maps-and-gis-data/download/south-america

[12] Sallares, V., Charvis, P., Flueh, E.R. and Bialas, J. (2005) The SALIERI Scientific Party Seismic Structure of the Carnegie Ridge and the Nature of the Galapagos Hot Spot. Geophysical Journal International, 161, 763-788. https://doi.org/10.1111/j.1365-246X.2005.02592.x

[13] http://sea-groups.com/Science_Technology.html

[14] Wessel, P., Sandwell, D.T. and Kim, S.-S. (2010) The Global Seamount Census. Oceanography, 123, 24-33. https://doi.org/10.5670/oceanog.2010.60

[15] http://alabamaquake.com/energy.html

[16] Mix, A.C., Tiedemann, R. and Blum, P. (2003) Leg 202 Shipboard Scientific Party. Proceedings of the Ocean Drilling Program (OPD) Initial Reports, Vol. 202, College Station, 1-145.

[17] Langmuir, C.H., Bender, J.F. and Batiza, R. (1986) Petrological and Tectonic Segmentation of the East Pacific Rise, $5^{\circ} \mathrm{C} 30^{\prime}-14^{\circ} \mathrm{C} 30^{\prime} \mathrm{N}$. Nature, 322, 422-429. https://doi.org/10.1038/322422a0

[18] Ocean Climate Laboratory (1999) Meridional Cross Section of Water Masses, Characterized by Dissolved Oxygen Concentrations in the Southeast Pacific. 
[19] Harpp, K.S., Wanless, V.D., Otto, R.H., Hoernle, K. and Werner, R. (2005) The Cocos and Carnegie Aseismic Ridge: A Trace Element Record of Long-Term Plume-Spreading Center Interaction. Journal of Petrology, 46, 109-133. https://doi.org/10.1093/petrology/egh064

[20] National Ocean Service, National Oceanic and Atmospheric Administration.

[21] Balzhiser, R.E., Samuels, M.R. and Eliassen, J.D. (1972) Chemical Engineering Thermodynamics. Prentice-Hall Inc., Upper Saddle River, 101.

[22] McCabe, W.L. and Smith, J.C. (1976) Unit Operations of Chemical Engineering. 3rd Edition, McGraw-Hill Inc., New York, 375.

[23] Coughanowr, D.R. (1991) Process Systems Analysis and Control. 2nd Edition, McGraw-Hill Inc., New York, 101.

[24] Soule, S.A., Cashman, K.V. and Kauahikaua, J.P. (2004) Examining Flow Emplacement through the Surface Morphology of Three Rapidly Emplaced, Solidified Lava Flows, Kilauea Volcano, Hawaii. Bulletin of Volcanology, 66, 1-14.

https://doi.org/10.1007/s00445-003-0291-0

[25] Richardson, M. (2004) College Physics. McGraw Hill, New York, 864-866.

[26] https://www.thoughtco.com/south-american-geology-1441058\#step-heading?utm_s ource=pinterest\&utm_medium=social\&utm_campaign=shareurlbuttons_nip

[27] Manrique, N.A.P. (2005) Sediment Distribution and Depositional Process on the Carnegie Ridge. Thesis, Texas A \& M University, College Station.

[28] Zhang, J., Andrus, R.D. and Juang, C.H. (2005) Normalized Shear Modulus and Material Damping Ratio Relationships. Journal of Geotechnical and Geoenvironmental Engineering, 131, 453-464.

https://doi.org/10.1061/(ASCE)1090-0241(2005)131:4(453)

[29] Bilek, S.L. (2009) Seismicity along the South American Subduction Zone: Review of Large Earthquakes, Tsunamis, and Subduction Zone Complexity. Tectonophyscis, 30, 1-13.

[30] Dumont, J.F., Benitez, S., Ortlieb, L., Lavenu, A., Guillier, B., Alvarado, A., Martinez, C., Jouannic, C., Toala, G., Vivanco, J. and Poli, J.T. (1996) Neotectonics of the Coastal Region of Ecuador: A New Pluridisciplinary Research Project. 3 rd ISAG, St. Malo, 17-19 September 1996, 175-178. 